\title{
Chemosymbiotic bivalves from the mud volcanoes of the Gulf of Cadiz, NE Atlantic, with descriptions of new species of Solemyidae, Lucinidae and Vesicomyidae
}

\author{
Graham Oliver ${ }^{1, \dagger}$, Clara F. Rodrigues ${ }^{2, \ddagger}$, Marina R. Cunha ${ }^{2, \S}$ \\ I BioSyB, National Museum of Wales, Cathays Park, Cardiff, CF10 3NP, Wales, UK 2 CESAM, Departa- \\ mento de Biologia, Universidade de Aveiro, Campus Universitário de Santiago, 3810-193 Aveiro, Portugal \\ † urn:lsid:zoobank.org:author:9330128A-D9C0-47E1-991E-438D9B8D4148 \\ † urn:lsid:zoobank.org:author:D54DAA7A-BE73-4E37-B5A1-760517AF1BA5 \\ § urn:lsid:zoobank.org:author:553A98B5-0AE0-424F-9ED5-EC50F129519C \\ Corresponding author: Graham Oliver (graham.oliver@museumwales.ac.uk) \\ Academic editor: Nathalie Yonow | Received 18 April 2011 | Accepted 2 June 2011 | Published 28 June 2011 \\ urn:lsid:zoobank.org:pub:5ECACOD4-083C-4223-AD2A-01810AA99BCD \\ Citation: Oliver G, Rodrigues CF, Cunha MR (2011) Chemosymbiotic bivalves from the mud volcanoes of the Gulf of \\ Cadiz, NE Atlantic, with descriptions of new species of Solemyidae, Lucinidae and Vesicomyidae. ZooKeys 113: 1-38. \\ doi: $10.3897 /$ zookeys.113.1402
}

\begin{abstract}
The chemosymbiotic bivalves collected from the mud volcanoes of the Gulf of Cadiz are reviewed. Of the thirteen species closely associated with chemosynthetic settings two Solemyidae, Solemya (Petrasma) elarraichensis sp. n. and Acharax gadirae sp. n., one Lucinidae, Lucinoma asapheus sp. n., and one Vesicomyidae, Isorropodon megadesmus sp. $\mathbf{n}$. are described and compared to close relatives of their respective families. The biodiversity and distribution of the chemosymbiotic bivalves in the Gulf of Cadiz are discussed and compared to the available information from other cold seeps in the Eastern Atlantic and Mediterranean. Although there is considerable similarity at the genus level between seep/mud volcano fields in the Eastern Atlantic and Mediterranean, there is little overlap at the species level. This indicates a high degree of endemism within chemosymbiotic bivalve assemblages.
\end{abstract}

\section{Keywords}

Bivalvia, chemosymbiotic, taxonomy, Gulf of Cadiz

Copyright G. Oliver et al. This is an open access article distributed under the terms of the Creative Commons Attribution License, which permits unrestricted use, distribution, and reproduction in any medium, provided the original author and source are credited. 


\section{Introduction}

Chemosynthetic bivalves are prominent constituents of the fauna of cold seeps and are represented in that setting by five families: Solemyidae, Lucinidae, Vesicomyidae, Thyasiridae and Mytilidae (Sibuet and Olu 1998, Sibuet and Olu-Le Roy 2002, Sahling et al. 2003, Levin 2005). Recently the presence of bacteria in the gills in species of Nucinella and Huxleyia has been demonstrated (Oliver and Taylor in preparation), confirming the previous inclusion of the Manzanellidae in this group (Cosel and Bouchet 2008).

The occurrence of chemosymbiotic bivalves in the extensive mud volcano fields of the Gulf of Cadiz was first reported by Pinheiro et al. (2003). Then followed a series of more in-depth studies: on polychaete commensals of solemyid hosts (Ravara et al. 2007); on the distribution and taxonomy of Thyasiridae (Rodrigues et al. 2008); on the phylogenetic relationships of Bathymodiolus mauritanicus Cosel (Génio et al. 2008) and on the molecular characterization of chemosymbiotic endosymbionts of solemyids, lucinids, thyasirids and mytilids (Rodrigues et al. 2010, Rodrigues and Duperron 2011).

Chemosynthetic bivalve faunas have been discovered elsewhere in the Eastern Atlantic, notably off tropical West Africa (Cosel and Salas 2001, Olu-Le Roy et al. 2007, Cosel and Olu 2009) and in the eastern Mediterranean (Salas and Woodside 2002, Olu-Le Roy et al. 2004, Carlier et al. 2010). For the Vesicomyidae, at the species level, these faunas are considered disparate (Cosel and Salas 2001, Krylova and Sahling 2010). Conversely studies on Bathymodiolus suggest that the species occurring in the Gulf of Cadiz is not only found along the West African margin but is amphi-Atlantic (Génio et al. 2008). The biogeographic patterns within these faunas are currently unresolved and require further taxonomic characterization, which this paper begins to address.

This paper intends to provide the taxonomic basis for the chemosynthetic bivalves in the Gulf of Cadiz and includes the description of two new species of Solemyidae, one new species of Lucinidae and one new species of Vesicomyidae. Notes on the biogeography of these taxa in the Atlantic are given with special emphasis on the relationships between the Eastern Mediterranean, Gulf of Cadiz and West Africa.

\section{Materials and methods}

Study area. The Gulf of Cadiz is located in the NE Atlantic Ocean between $34^{\circ} \mathrm{N}$ and $37^{\circ} 15^{\prime} \mathrm{N}$ and $6^{\circ} \mathrm{W}$ to $9^{\circ} 45^{\prime} \mathrm{W}$. It is enclosed by the southern Iberian and northern Moroccan margins, west of Gibraltar Strait. The geological history of the Gulf of Cadiz is intimately related to plate tectonic interaction between Southern Eurasia and North Africa and is driven by two major mechanisms: a) subduction associated with the westward emplacement of the Gibraltar Arc and formation of the Gulf of Cadiz accretionary wedge, probably not active at present and b) oblique lithosphere collision 
between Iberia and Nubia, active at present and causing active thrusting (Zitellini et al. 2009). It is now well established that the whole area is under compressive deformation and that mud volcanism and processes associated with the escape of hydrocarbon-rich fluids sustain a broad diversity of chemosynthetic assemblages. This extensive area encompasses over forty mud volcanoes (here after as MV), at depths ranging from 200 to $4000 \mathrm{~m}$ (confirmed by coring) (Mazurenko et al. 2002, Pinheiro et al. 2003, Magalhães 2007), and active methane seepage has been documented on several locations (Kenyon et al. 2000, Gardner 2001, Niemann et al. 2006, Stadnitskaia et al. 2006, Hensen et al. 2007). Biological samples were available from 30 sites but for this study only thirteen MVs and one structure (PDE) yielded chemosymbiotic bivalves (Fig. 1).

In the shallow Moroccan margin the El Arraiche field encompasses Renard Ridge (including Pen Duick Escarpment), Vernadsky Ridge and several mud volcanoes (e.g.

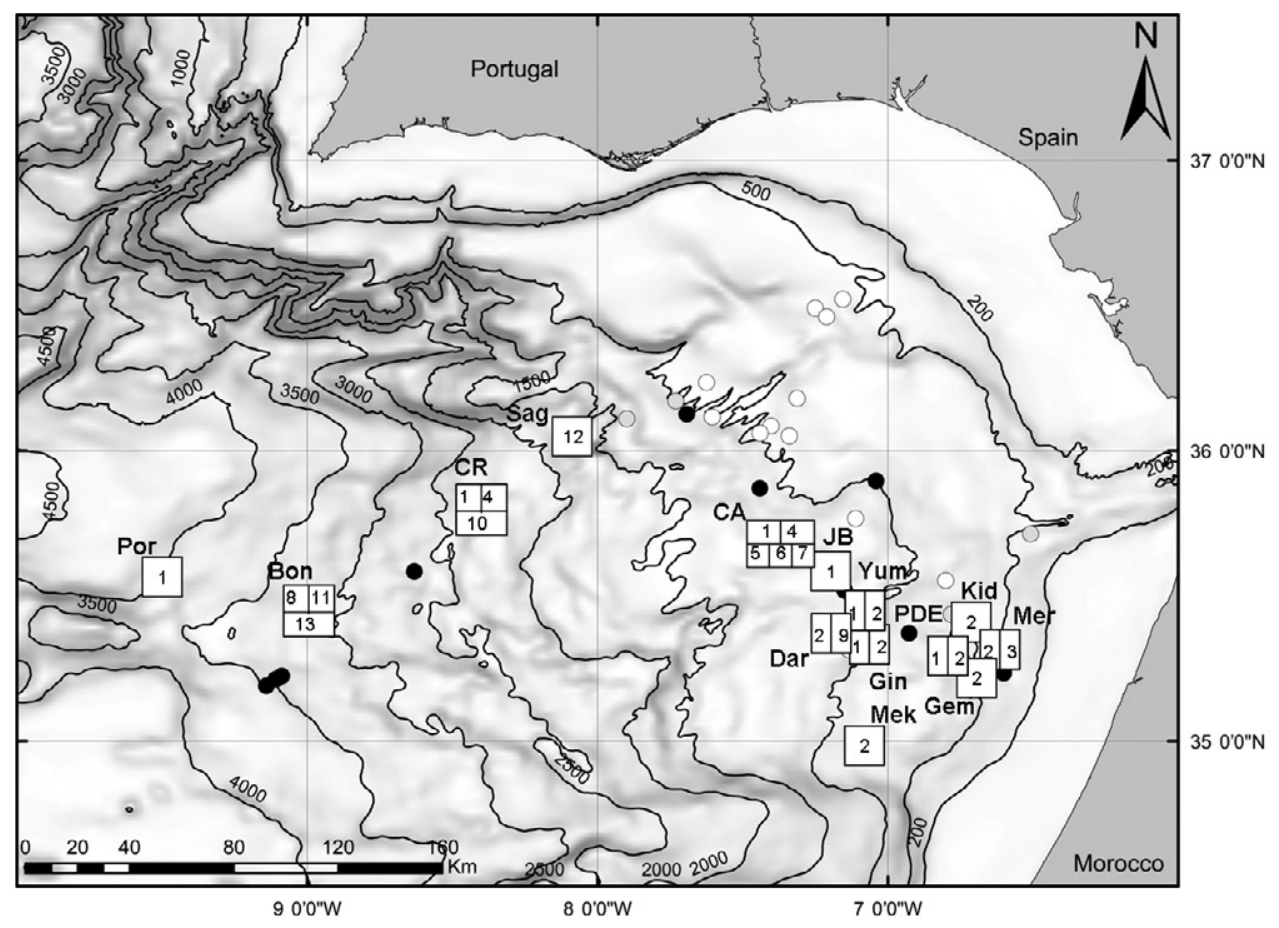

Figure I. Map of the study area (Gulf of Cadiz) and location of sampling sites. squares with numbers, mud volcanoes with chemosymbiotic bivalves: full black circles, mud volcanoes visited during the study but bivalves not found: grey circles: mud volcanoes and other structures not visited during the study. Bon, Bonjardim MV; CA, Captain Arutyunov MV; CR, Carlos Ribeiro MV; Dar, Darwin MV; Gem, Gemini MV; Gin, Ginsburg; JB, Jesus Baraza MV; Kid, Kidd MV; Mek, Mèknes MV; Mer, Mercator MV; PDE, Pen Duick Escarpment; Por, Porto MV; Sag, Sagres MV; Yum, Yuma MV. The numbers inside the squares indicate the presence of the following species. I Acharax gadirae $\mathbf{2}$ Petrasma elarraichensis 3 Lucinoma asapheus 4 Thyasira vulcolutre 5 Spinaxinus sentosus $\mathbf{6}$ Isorropodon megadesmus 7 Isorropodon sp. indet. 8 Christineconcha cf. regab 9 Bathymodiolus mauritanicus 10 Idas sp. II Laubiericoncha chuni (empty shells only) $\mathbf{2}$ Callogonia cyrili (empty shells only) $\mathbf{3}$ Pliocardia sp. (empty shells only). 
Al Idrisi, Mercator, Fíuza, Gemini, Kidd MVs) located at depths from 200 to approximately $600 \mathrm{~m}$ depth: The proximity to the euphotic zone and to the African coast adds to the great productivity observed in the area. Dead cold-water scleractinean coral reefs, carbonate crusts and exposed carbonate chimneys characterize the Renard and Vernadsky Ridges. Carbonate crusts, rock blocks and clasts are often found in the craters of the shallow mud volcanoes where mild seepage activity has been recorded (Van Rensbergen et al. 2005). Mercator MV, one of the shallowest mud volcanoes differs significantly from the other mud volcanoes by the high chloride enrichment of its pore water (Van Rensbergen et al. 2005). The top of Mercator MV shows patches of disturbed sediments from which gas venting is occasionally observed. Solitary corals (Caryophyllia sp.), accompanied by Cidaridae echinoids and Onuphidae polychaetes (Hyalinoecia) are the most conspicuous organisms seen during video surveys of the Mercator MV crater.

The western Moroccan field comprises several mud volcanoes (e.g. Meknès, Student, Yuma, Ginsburg, Jesus Baraza, Darwin MVs) at intermediate depths (700$1200 \mathrm{~m}$ ) located along an extensive province of carbonate and mostly dead cold-water coral mounds. The widespread presence of authigenic carbonates and also extensive Neptunea and Bathymodiolus graveyards (usually within the crater of the mud volcanoes) suggest that this was a very active seepage area in the past. Darwin MV differs from the others in this area because its crater is completely covered by large carbonate slabs and crusts. The fissures among slabs and depressions with scattered crust are filled with abundant shell ash and occasionally small clumps of living Bathymodiolus mauritanicus Cosel, 2002. Meknès MV is the southernmost Moroccan mud volcano rising isolated among an extensive field of small coral mounds. The crater is formed by stiff, sometimes heavily disturbed, green mud breccia with scattered clasts and a striking large number of empty shells of the gastropod Neptunea. Except for a few Paromola individuals, living megafauna is rarely sighted in the crater

The deep-water field (1300-4000m), mostly within the Portuguese margin includes several mud volcanoes (e.g. Captain Arutyunov, Carlos Ribeiro, Bonjardim and Porto MVs) that are aligned along major crustal strike-slip faults associated with the African-Eurasian plate boundary (Duarte et al. 2005). Gas hydrates were recovered from these mud volcanoes and the methane concentrations yield the highest records from the Gulf of Cadiz (Kenyon et al. 2000, 2001, 2002, 2003, 2006; Akhmetzhanov et al. 2007, 2008). Video surveys of these deeper mud volcanoes often show conspicuous siboglinid fields (e.g. Porto MV) in the active craters and exuberant sponge and gorgonian patches at the crater rim and upper flank (e.g. Carlos Ribeiro MV).

Sampling. Samples were collected between 2002 and 2006 during TTR (Training Through Research) 12, TTR 14, TTR15 and TTR16 cruises onboard RV Prof. Logachev and MSM.01-03 cruise onboard RV Maria S. Merian (IFM-GEOMAR). The material was collected using TV-assisted grabs or USNEL box-corers. Occasionally faunal specimens were also recovered from Reineck box-corer, multiple corer or lander samples that were carried out for different purposes. Whenever possible the specimens were sorted onboard and preserved in 70 or $96 \%$ ethanol (the latter preserved for molecular analysis). 
Deposition of samples. The majority of specimens are deposited in the Biological Research Collection of the Department of Biology, University of Aveiro but the holotype; some paratypes and selected specimens are deposited in the National Museum of Wales.

Institutional abbreviations. DBUA, Department of Biology, University of Aveiro (Biological Research Collection); IFM-GEOMAR, Institut für Meereskunde - Forschungszentrum für marine Geowissenschaften; IOC-UNESCO, Intergovernmental Oceanographic Commission - United Nations Educational, Scientific and Cultural Organization; NMW.Z, National Museum of Wales, Cardiff, Great Britain.

Measurements. All measurements were made using Sylvac ${ }^{\mathrm{TM}}$ vernier calipers accurate to $0.01 \mathrm{~mm}$ but are given to the nearest tenth.

\section{Systematics}

\section{Order Solemyoida Dall, 1889 \\ Superfamily Solemyoidea Gray, 1840 \\ Family Solemyidae Gray, 1840}

Solemyids are among the most ancient bivalves dating from the Paleozoic (Métivier and Cosel 1993). They are protobranch in organization and characterized by an elongate shell (up to $220 \mathrm{~mm}$ ) with a posteriorly situated toothless hinge. The thick brown periostracum is much larger than the calcified part of the valve and is folded inwards by the muscular mantle edge upon closing of the valves (Métivier and Cosel 1993).

Solemyidae taxonomy is complex. Taylor et al. (2008) and Kamenev (2009) recognized two extant genera, Solemya and Acharax, with a further four subgenera within Solemya, namely Petrasma, Austrosolemya Solemyarina and Zesolemya. Solemyids, other than Acharax are generally found at continental shelf and upper-slope depths (0 to $600 \mathrm{~m}$ ), although Solemya (Petrasma) pervernicosa has been recorded at $1500 \mathrm{~m}$ (Kamenev 2009). Acharax is generally restricted to deep-sea settings from $-400 \mathrm{~m}$ on the continental slope to the deepest sites of the Japan Trench (Neulinger et al. 2006). Shallow dwelling solemyids live in sediments with high organic matter content, often at reduced oxygen concentrations. Hydrogen sulphide is frequently present due to sulphate reduction coupled with organic matter degradation (Conway et al. 1992). In contrast, the genus Acharax has been recovered from cold seep locations (see review by Sibuet and Olu 1998) and in sediments influenced by hydrothermal venting (Juniper et al. 1992, Métivier and Cosel 1993). Acharax species are morphologically similar but molecular data suggests a degree of cryptic speciation (Neulinger et al. 2006).

Superficially, all solemyids appear so similar that specimens discovered at various deep-sea sites might have been misclassified as Solemya (see review by Sibuet and Olu 1998). 


\section{Genus Solemya Lamarck, 1818}

\section{Subgenus Petrasma Dall, 1908}

Type species. Solemya borealis Totten, 1834

Definition. As given by Taylor et al. 2008. Ligament wholly internal, supported by a buttress and lacking posterior or lateral extensions.

\section{Solemya (Petrasma) elarraichensis sp. $\mathbf{n}$.} urn:1sid:zoobank.org:act:32A6013D-4378-462A-BABA-4AFC4D26FB1E http://species-id.net/wiki/Solemya_(Petrasma)_elarraichensis

Figs 2, 3A-D, 4

Material examined. Holotype: one specimen, TTR14, stn AT528GR, El Arraiche field, Kidd MV, 35²5.304'N, 06²3.972'W, 489m, 03 August 2004, NMWZ.2010.4.1

Paratypes: ten specimens, same data as holotype, NMWZ.2010.4.2; seven specimens, TTR15, stn AT569GR, El Arraiche field, Mercator MV, 35¹7.917'N, 0638.717'W, 358m, 25 July 2007, DBUA.

Other material examined: eight juveniles specimens, same data as holotype; two specimens, TTR12, stn AT407GR, El Arraiche field, Pen Duick Escarpment, $35^{\circ} 17.695^{\prime} \mathrm{N}, 06^{\circ} 47.082^{\prime} \mathrm{W}, 560 \mathrm{~m}, 15$ July 2002; three specimens, TTR14, stn AT560B, El Arraiche field, Kidd MV, 35²5.306'N, 0643.976'W, 498m, 8 August 2004; one specimen, TTR15, stn AT586GR, Western Moroccan field, Meknès MV, $34^{\circ} 59.146^{\prime} \mathrm{N}, 07^{\circ} 04.380^{\prime} \mathrm{W}, 701 \mathrm{~m}, 28$ July 2005; four specimens, TTR16, stn AT604GR, Western Moroccan field, Yuma MV, 35²5.820'N, 0706.330'W, 1030m, 29 May 2006; two specimens, TTR16, stn AT607GR, Western Moroccan field, Ginsburg MV, 35²2.677'N, 0704.979'W, 983m, 29 May 2006.

\section{Measurements (in $\mathbf{m m}$ )}

\begin{tabular}{l|l|c|c|c}
\hline & Station & Length & Height & Posterior Length \\
\hline Holotype & AT528GR & 33.8 & 14.1 & 9.8 \\
\hline Paratype & AT528GR & 29.2 & 10.5 & 8.0 \\
\hline Paratype & AT528GR & 25.6 & 10.0 & 6.2 \\
\hline Paratype & AT528GR & 23.1 & 8.4 & 6.0 \\
\hline Paratype & AT528GR & 14.7 & 5.3 & 3.6 \\
\hline Paratype & AT528GR & 22.0 & 7.9 & 6.0 \\
\hline Paratype & AT528GR & 11.6 & 4.7 & 2.5 \\
\hline Paratype & AT528GR & 17.6 & 6.8 & 5.2 \\
\hline
\end{tabular}

Description. Shell (Figs 2, 3): to 35mm in length. Fragile. Equivalve. Inequilateral, beaks situated at $1 / 4$ length of shell from posterior margin. Outline subcylindrical, compressed, length about 2.6 times height, slightly deeper towards the anterior, dorsal and ventral margins subparallel, anterior margin more broadly rounded than ante- 


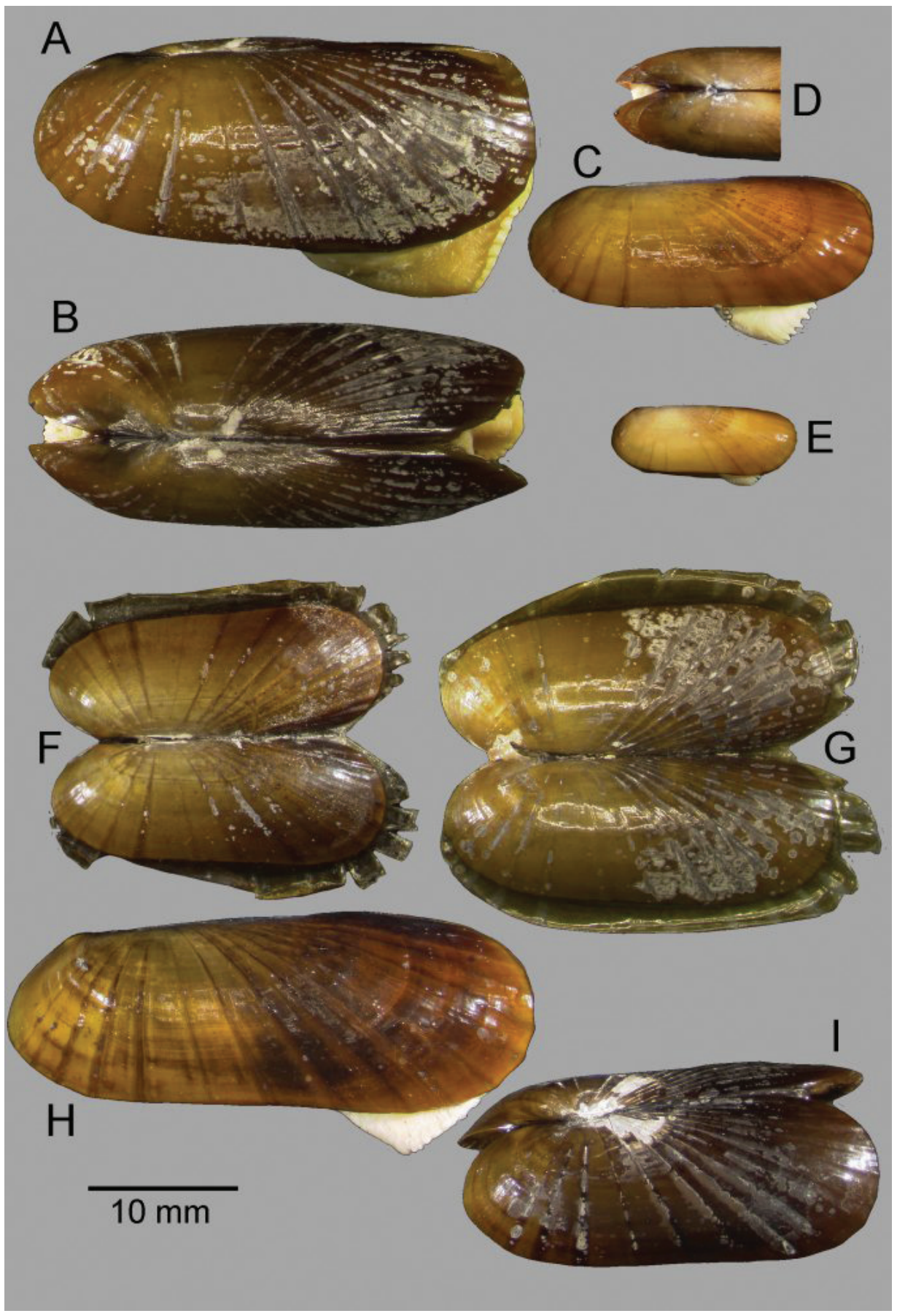

Figure 2. Solemya (Petrasma) elarraichensis sp. n. A-E from Kidd MV; A-B lateral and dorsal views of holotype $\mathbf{C}-\mathbf{D}$ lateral and dorsal views of medium sized paratype $\mathbf{E}$ lateral view of small paratype. $\mathbf{F}$ paired valves from Pen Duick Escarpment $\mathbf{G}$ paired valves from Mercator MV $\mathbf{H}$ lateral view of specimen from Meknès MV I lateral view of shell from Yuma MV. 
rior, posterior dorsal margin projecting a little. Beaks indistinct, umbos sunken. Hinge teeth absent. Ligament primarily internal, supported by a prominent chondrophore that extends only slightly as a chondrophore ridge around the posterior adductor, lacking posterior and anterior extensions but a small roughly heart shaped area is present in front of the chondrophore and this is also visible externally just behind the beaks. Periostracum persistent and extending well beyond the shell margin, initially yellowish brown in colour but darkening with growth to a dark chestnut brown. Sculpture of weak radial ridges, 5-6 over the posterior and 10-12 over median and anterior. Adductor scars impressed, dorsal part of posterior scar angulate where bounded by chondrophore ridge, anterior adductor scar larger, spatulate in outline.

Anatomy (Figs 3G, 4): The posterior siphonal opening is surrounded by a series of papillae: A single large dorsal papilla (dp) lies above two smaller but still large papillae (dmp) on the dorsal margin of the opening, below these is a short smooth section (sa) followed by a series of papillae increasing in size towards the ventral margin, there are 6 primary papillae (psp) on either side and a single ventral median papillae, between these on the inner side are smaller papillae (ssp); a pair of subsiphonal ridges (ssr) are present below the siphonal crown.

The mantle edge is fused from the posterior siphon for half the length of the ventral margin where there is a large anterior pedal gape. The mantle edge surrounding the rear of the foot bears a few tabulate papillae (pgp). The anterior dorsal mantle edge is prominently papillate (dap) and there is a single papilla on the junction of the mantle edge anterior of the anterior adductor muscle (admp). The foot is very large with a broad oval sole, this fringed by large papillae, all equal in size. The ctenidium is large with numerous laminar filaments attached to a prominent gill axis. The palps are short, twisted and flattened with cup shaped terminations. The gut is present but difficult to examine due to its small dimensions but the hind gut and rectum were easily visible.

Distribution. Solemya (P.) elarraichensis is presently only known from the mud volcano fields in the Gulf of Cadiz, Eastern Atlantic. The majority of specimens have been taken from the El Arraiche field off the coast of Morocco in Kidd, Fíuza and Mercator MVs and the Pen Duick Escarpment at depths between 358-560m. A few specimens have been taken from the Western Moroccan field at the Meknès, Yuma, Ginsburg and Darwin MVs at the slightly deeper range of 700-1115m.

Etymology. elarraichensis, denoting the geographic origin of the type locality; the El Arraiche field.

Remarks. The form of the ligament, which is primarily internal, supported by a chondrophore and lacks any lateral or anterior extensions, confirms the placement of S. (P.) elarraichensis in the subgenus Petrasma Dall, 1908 (Taylor et al. 2008). Some of the specimens carry an initial identification of "cf. Solemya togata" as might be expected from the proximity to the Mediterranean but the ligament of Solemya s.s. has prominent anterior extensions (Fig. 3E).

The subgenus Petrasma is not known from the North-East Atlantic but is represented in the Western Atlantic by three species. Two species are known from near shore waters off the northeast coast of the USA: $S$. (P.) velum (Say, 1822) and $S$. (P.) borealis 

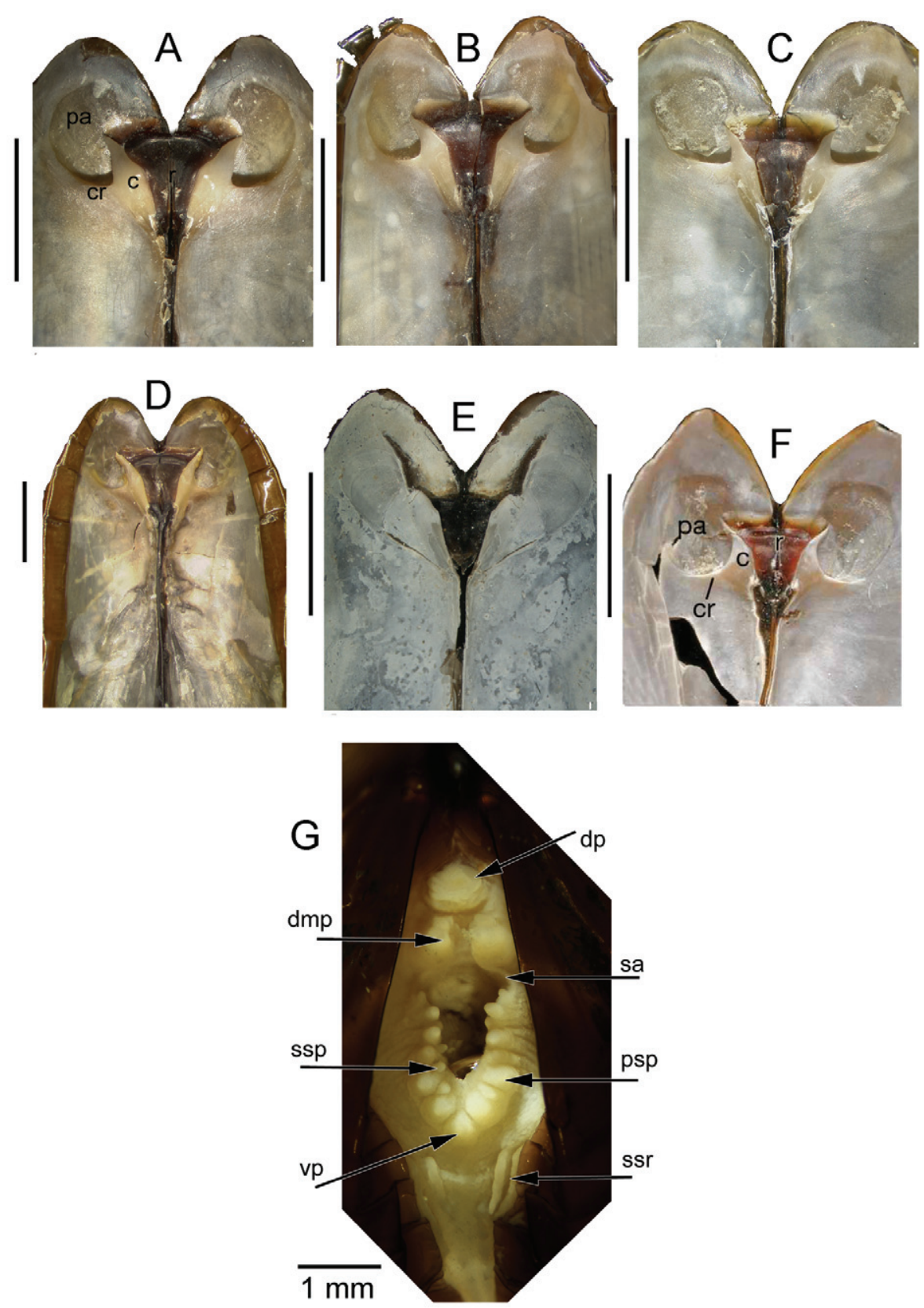

Figure 3. A-F Internal views of ligament, scale bars $=5 \mathrm{~mm}$. A-D Solemya (Petrasma) elarraichensis sp. n. from A Kidd MV B Pen Duick Escarpment C Mercator MV D Yuma MV. E Solemya togata, Mediterranean F S. (P.) velum, Rhode Island (from Taylor et al. 2009). c, chondrophore; cr chondrophore ridge; pa, posterior adductor scar; r, resilium. G posterior siphon of S. (P.) elarraichensis. dp, dorsal papilla; dmp, dorsal marginal papillae; psp, primary siphonal papillae; sa, smooth area; ssp, secondary siphonal papillae; ssr, subsiphonal ridge; vp, ventral papilla. 
(Totten, 1834). The third, S. (P.) occidentalis (Deshayes 1857) is known from the warm waters of Florida, Caribbean and S. America (Mikkelsen and Bieler 2008).

We note that the curvature of the chondrophore and chondrophore ridge is circular in $S$. (P.) velum (Fig. 3F) but angular in $S$. (P.) elarraichensis (Figs 3A-D). Furthermore, the siphonal papillae of $S$. (P.) velum are by comparison less in number and reduced in development (Morse 1913, Taylor et al. 2008).

Abbott (1974) following Morse (1913) noted that the siphon of $S$. (P.). borealis differed markedly from that of $S$. (P.) velum, confirming that siphonal characters were important for distinguishing species. In $S$. (P.) borealis, the ventral-most dorsal marginal papillae are very large, and as big as the dorsal papilla, and much larger than any of the ventral papillae. This contrasts with the condition in $S$. (P.) elarraichensis where the ventral-most dorsal marginal papillae are smaller than the dorsal papilla and where the ventral papillae are fewer in number and distinctly increasing in size ventrally, with the ventral-most papillae equal in size to the dorsal marginal papillae. Conway et al. (1992), following Barnard (in Reid 1980) suggested that $S$. (P.) borealis lacked a gut and this would be in contrast with $S$. (P.) velum and $S$. (P.) elarraichensis.

The character of the ligament and chondrophore are rather similar in $S$. (P.) elarraichensis and $S$. (P.) borealis.

Abbott (1974) and Mikkelsen and Bieler (2008) note that $S$. (P.) occidentalis lacks any perceptible chondrophore ridge and give this as the main characteristic separating $S$. (P.) occidentalis from $S$. (P.) velum and, therefore, also from $S$. (P.) elarraichensis.

Ecologically $S .(P$.$) velum and S .(P$.$) borealis are very different from S$. (P.) elarraichensis in that they are not associated with deep-water methane seeps. In contrast they are found in sublittoral or shallow shelf settings with high organic enrichment (Morse 1913 in Conway et al. 1992). Mikkelsen and Bieler (2008) give a similar habitat for S. (P.) occidentalis (Deshayes, 1857) noting its occurrence in mangrove channels and around sewage outfalls.

Given the above differences in habitat and form we conclude that none of the Atlantic species is amphi-Atlantic, unlike $S$. (P.) pervernicosa Kuroda, 1948, which is considered to be amphi-Pacific by Kamenev (2009). If any of the Western Atlantic species were amphi-Atlantic it is unclear why, in the Eastern Atlantic, they should be absent from their typical settings (which are plentiful) and found only in deep water methane seeps.

Other North Atlantic species referred to as Solemya, S. grandis Verrill and Bush, 1898 and S. caribbaea Vokes, 1970 are excluded here because both belong to the genus Acharax (Abbott 1974).

A solemyid living at a pockmark, at a depth of $1607 \mathrm{~m}$, has been reported from the Eastern Mediterranean (Rodrigues et al. 2011). Unfortunately the small, single specimen was damaged and its taxonomic affinities remain unclear.

In conclusion, there are sufficient morphological and ecological grounds for considering the Gulf of Cadiz species of Petrasma to be new to science. 


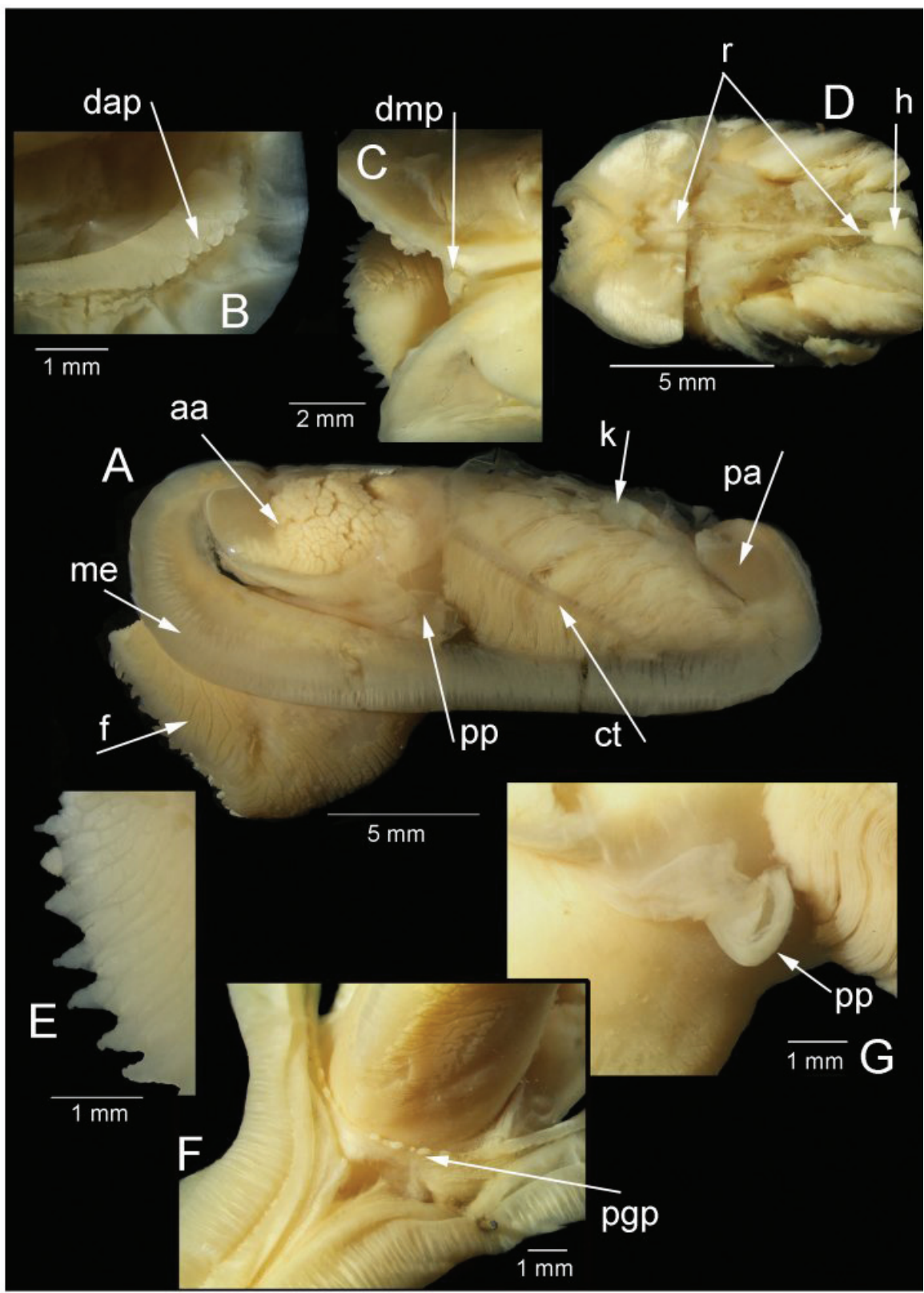

Figure 4. Solemya (Petrasma) elarraichensis sp. n., Pen Duick, stn. AT407GR, 560m. Anatomy. A whole animal viewed from left side $\mathbf{B}$ papillae on dorsal anterior mantle edge $\mathbf{C}$ single, large papilla in dorsal median position $\mathbf{D}$ posterior dorsal dissection showing rectum passing through heart $\mathbf{E}$ marginal papillae on foot $\mathbf{F}$ papillae on mantle edge surrounding pedal gape $\mathbf{G}$ palp. aa, anterior adductor muscle. ct, ctenidium. dap, dorsal anterior papillae. dmp, dorsal median papilla. $\mathrm{f}$, foot. h, heart. $\mathrm{k}$, kidney. me, mantle edge. pa, posterior adductor muscle. pgp, papillae surrounding pedal gape. pp, palp. r, rectum. 


\section{Genus Acharax Dall, 1908}

Type species: Solemya johnsoni Dall, 1891

Definition. As given by Taylor et al. 2008. Ligament external, as a high arched band.

\section{Acharax gadirae sp. $\mathbf{n}$.}

urn:lsid:zoobank.org:act:A2467D10-D03D-4271-9993-0C2A6CD22944

http://species-id.net/wiki/Acharax_gadirae

Figs 5-6

Type material. Holotype: one specimen, TTR12, stn AT391GR, Western Moroccan field, Jesus Baraza MV, $35^{\circ} 35.439^{\prime} \mathrm{N}, 07^{\circ} 12.264^{\prime} \mathrm{W}, 1105 \mathrm{~m}, 09$ July 2002 , NMWZ.2010.4.3.

Paratypes: one specimen, same data as holotype, DBUA; one shell, TTR 12, stn AT392G, deep-water field, Captain Arutyunov MV, 35 39.658' N, $07^{\circ} 20.018^{\prime} \mathrm{W}$, 1320m, 9 July 2002, DBUA; one shell, TTR 16, stn AT607GR, Western Mo-

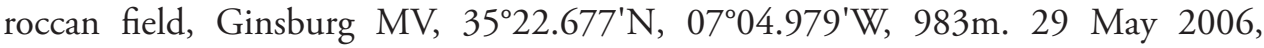
NMWZ.2010.4.4.

Other material examined: one specimen, TTR16, stn AT602GR, El Arraiche field, Pen Duick Escarpment, 35¹7.693'N, 06²7.089'W, 556m, 28 May 2006; one specimen, TTR16, stn AT604GR, Western Moroccan field, Yuma MV, 3525.820'N, $07^{\circ} 06.330^{\prime} \mathrm{W}, 1030 \mathrm{~m}, 29$ May 2006; one specimen, TTR16, stn AT605GR, same locality, $35^{\circ} 25.046^{\prime} \mathrm{N}, 07^{\circ} 05.450^{\prime} \mathrm{W}, 975 \mathrm{~m}, 29$ May 2006; one specimen, TTR16, stn AT615GR, deep-water field, Carlos Ribeiro MV, 35⒋ $238^{\prime} \mathrm{N}, 08^{\circ} 25.272^{\prime} \mathrm{W}, 2200 \mathrm{~m}$, 31 May 2006; one specimen, TTR16, stn AT617K, same locality, 35\%47.246'N, $08^{\circ} 25.303^{\prime} \mathrm{W}, 2230 \mathrm{~m}, 31$ May 2006; two specimens, MSM01.03, stn 145, deep-water field, Porto MV, 35³3.773'N, 09³0.416'W, 3902m, 3 June 2006.

Measurements (in mm)

\begin{tabular}{l|c|c|c|c|c|c}
\hline & Station & $\begin{array}{c}\text { Calcified } \\
\text { Shell Length }\end{array}$ & $\begin{array}{c}\text { Calcified } \\
\text { Shell Height }\end{array}$ & $\begin{array}{c}\text { Calcified Shell } \\
\text { Posterior Length }\end{array}$ & $\begin{array}{c}\text { Actual } \\
\text { length }\end{array}$ & $\begin{array}{c}\text { Anterior Ribs/ } \\
\text { Posterior Ribs }\end{array}$ \\
\hline Holotype & AT391GR & 56.3 & 21.1 & 14.5 & 59.5 & $9 / 4$ \\
\hline Paratype & AT391GR & 60.0 & 22.0 & 14.2 & 65.4 & $8 / 4$ \\
\hline Paratype & AT392GR & 67.0 & 25.0 & 19.1 & 85.0 & $8 / 4$ \\
\hline Paratype & AT607 GR & 42.8 & 15.9 & 10.6 & 48.9 & $9 / / 4$ \\
\hline
\end{tabular}

Description (Fig. 5) Calcified shell to $67 \mathrm{~mm}$ in length, to $85 \mathrm{~mm}$ including periostracal fringe. Robust. Equivalve. Inequilateral, beaks situated at 1/4 length of shell from posterior margin. Outline subcylindrical, compressed, calcified shell length about 3 times height, slightly deeper towards the anterior, dorsal and ventral margins subparallel, anterior margin more broadly rounded than anterior, posterior dorsal margin projecting a little. Including periostracal fringe, anterior appears greatly expanded compared 
with posterior. Beaks indistinct, umbos sunken. Hinge teeth absent. Ligament external, as a high arched band posterior of the beaks and supported by a thickened shell margin; an oval area of ligament is present immediately behind the beaks and visible internally, anterior of the beaks shell margins fused by periostracal material along entire dorsal margins. Periostracum persistent and extending well beyond the shell margin, initially yellowish brown in colour but darkening with growth to dark brown and black; periostracal frill thickened over ribs but entire. Sculpture of radial ridges, 4 closely spaced over the posterior; median area almost smooth with 2-3 low ribs; anterior with 8-9 deeply cut ribs. Adductor scars impressed, posterior scar subcircular, anterior adductor scar larger, spatulate in outline. Anterior inner shell margin scalloped corresponding to radial ribs.

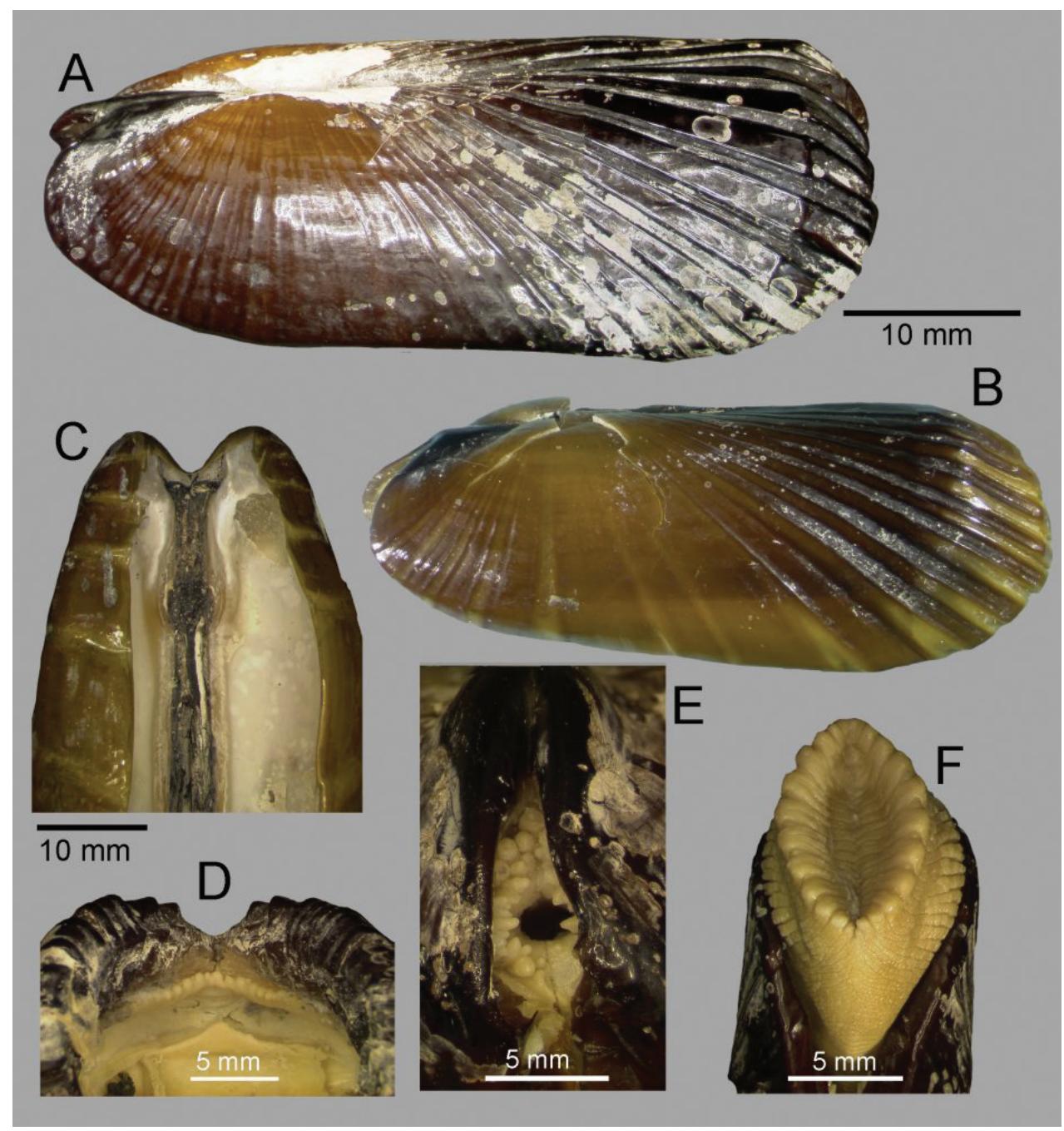

Figure 5. A-F Acharax gadirae sp. n. A Holotype, stn. AT391GR, Jesus Baraza MV B Paratype, stn. AT607GR, Ginsburg MV C interior view of posterior ligament, stn. AT392GR, Jesus Baraza MV D anterior dorsal mantle edge, st. AT391GR E posterior siphon, st AT391GR F foot, stn. AT391GR 


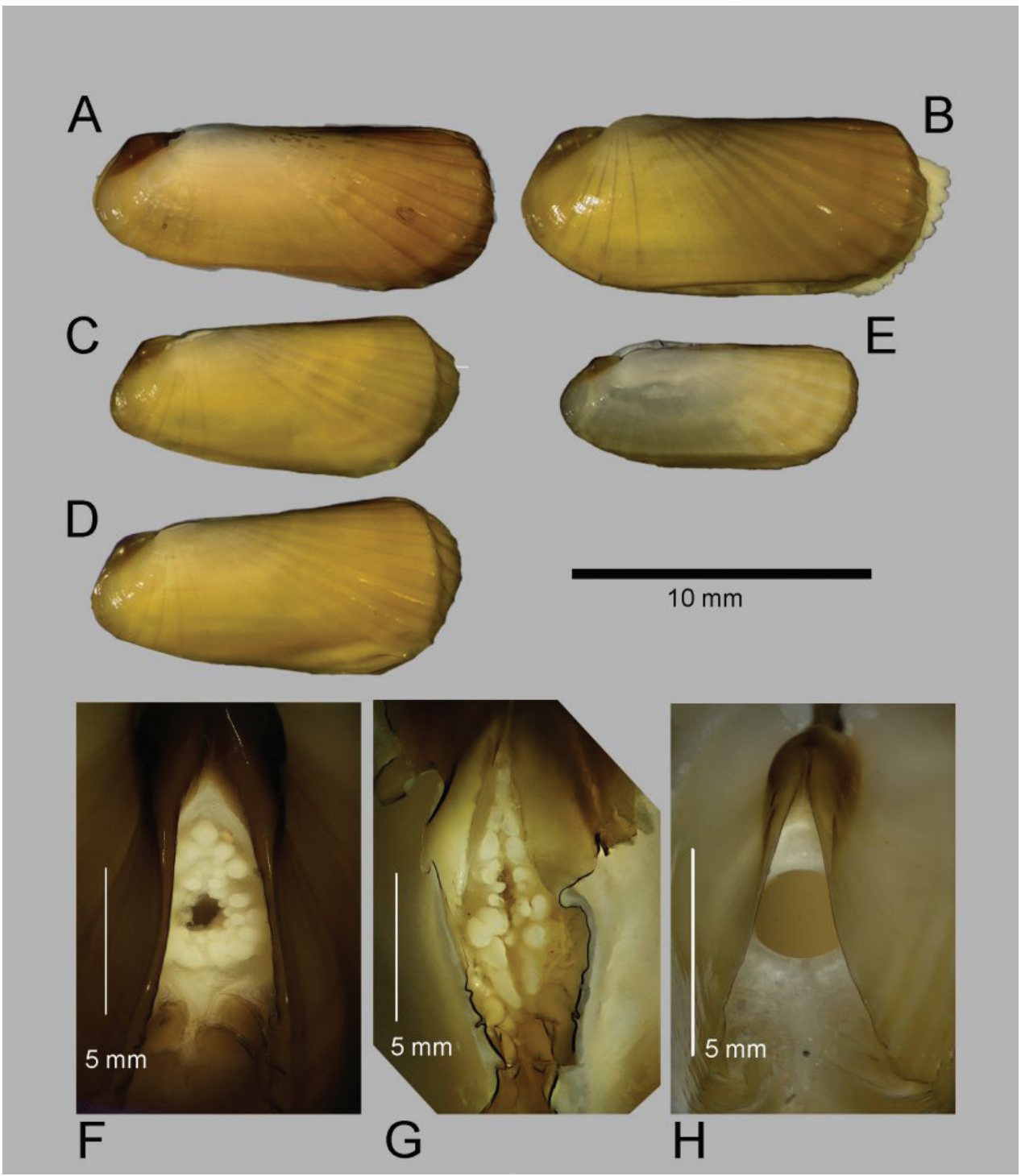

Figure 6. Acharax gadirae sp. n. A stn. AT602GR, Pen Duick Escarpment B stn. 145, Porto mud volcano C-D stns AT617GR \& AT61GR, Carlos Ribeiro mud volcano E stn. 199, Capt Arutyunov mud volcano. $\mathbf{F}-\mathbf{E}$ posterior siphon $\mathbf{F}$ specimen A $\mathbf{G}$ specimen D $\mathbf{H}$ specimen $\mathrm{E}$.

Posterior siphonal opening surrounded by a series of papillae (Fig. 5E): A single large dorsal papilla (dp) lies above 2-3 pairs of slightly smaller papillae (dmp) on the dorsal margin of the opening, below these surrounding the opening is a series of approximately alternating large and small papillae with those most ventral the largest.

The mantle edge is fused from the posterior siphon for half the length of the ventral margin where there is a large anterior pedal gape. The mantle edge surrounding the rear of the foot is papillate. The anterior dorsal mantle edge is prominently papillate (Fig. 
5D). The foot is very large with a broad oval sole, the margin interdigitates between large and small blunt papillae. The ctenidium is large with numerous laminar filaments attached to a prominent gill axis. The palps are short, twisted and flattened with cup shaped terminations. The presence or absence of a gut could not be confirmed.

Distribution. Acharax gadirae is presently only known from the mud volcano fields in the Gulf of Cadiz, Eastern Atlantic. The specimens have been taken from the Western Moroccan field at Yuma, Ginsburg and Jesus Baraza MVs, and from the deepwater field at Captain Arutyunov, Carlos Ribeiro and Porto MVs at depths between 975 to $3902 \mathrm{~m}$. A single specimen was recovered from the shallower El Arraiche field in Pen Duick Escarpment at $556 \mathrm{~m}$.

Etymology. gadirae, from the Phoenician "Gadir" the original name for Cadiz and meaning "walled fortification" and also the root of many Moroccan names such as Agadir. Named to indicate the widespread range across the Moroccan and Iberian margins.

Remarks. The genus Acharax is recognizable from the large external ligament and the generic placement of $A$. gadirae is confirmed.

The genus is rare in the Atlantic Ocean unlike the situation in the Pacific where species of Acharax are frequently recorded from chemosynthetic settings (Neulinger et al. 2006). Only two species are known from the Atlantic. Acharax grandis (Verrill and Bush 1898) is known only from the original material collected from depths between 548 and 2926m in the region of the New York Bight. Acharax caribbaea (Vokes 1970) again is only recorded from the original material collected from a depth of $350 \mathrm{~m}$ off Colombia in the Caribbean Sea. However, the genus is recorded in recent studies from both the Gulf of Mexico (Carney 1994) and the Barbados prism (Olu et al. 1997) but the species are not identified.

Acharax grandis differs from both $A$. gadirae and A. caribbaea in being less inequilateral with the beaks distinctly more towards the mid-line. Acharax caribbaea differs from both $A$. gadirae and $A$. grandis in having very few (4) anterior ribs compared with the 6-8 on $A$. grandis and 8-9 on A. gadirae of similar size. Unfortunately, there are no anatomical data for either $A$. grandis or $A$. caribbaea, making a thorough comparison impractical.

There are no given ecological data for either $A$. grandis or $A$. caribbaea. The type locality for $A$. grandis, which is the region around the Hudson Shelf and Canyon, has no recorded seep or vent activity. In contrast the region around the type locality of $A$. caribbaea is known for a variety of chemosynthetic settings (Carney 1994).

The bathymetric range of Acharax in the Gulf of Cadiz is large, 556-3902m and specimens have been taken at many mud volcanoes raising the possibility that more than one species is involved. Unfortunately the specimens from the abyssal sites are all small about $10 \mathrm{~mm}$ or less making comparison with the large specimens from the bathyal sites inconclusive. The specimens from Carlos Ribeiro MV (2200m) (Fig. 6CD) are prominently wedge shaped in outline compared with the specimen from Porto MV (3902m) (Fig. 6B). The latter is not dissimilar to those from Capt. Arutyunov MV (1325m) (Fig. 6E) with the specimen from Pen Duick Escarpment (556m) (Fig. 6A) somewhat more elongate but not as wedge shaped as those from Carlos Ribeiro MV. 
The specimens from the Capt Arutyunov MV are most problematic in that the siphonal opening appears to be devoid of any surrounding tentacles or papillae (Fig. 6H). This does not appear to be a function of size as similar specimens from other sites have siphonal papillae. Should this observation be confirmed in further material it would be appropriate to describe this as a separate species. Comparing the siphonal papillae of specimens from Pen Duick Escarpment (Fig. 6F) and Carlos Ribeiro MV (Fig. 6G) indicates a more complex arrangement in the latter but, with so few specimens, this is inconclusive.

\section{Superfamily Lucinoidea Fleming, 1828 Family Lucinidae Fleming, 1828}

The Lucinidae is, by far, the most disparate and species-rich family of chemosymbiotic bivalves and are thoroughly reviewed by Taylor and Glover (2006). Although they occupy a wide range of habitats, they are relatively infrequent in deep-sea settings (Taylor and Glover 2009). Some species are associated with cold seeps and mud volcanoes, oxygen minimum zones and a single species is known from a hydrothermal vent (Taylor and Glover 2006). Of most frequent occurrence in, but not exclusive to, deep-sea settings is the genus Lucinoma (Salas and Woodside 2002, Oliver and Holmes 2006a, Cosel 2006, Cosel and Bouchet 2008). Oliver and Holmes (2006a) and Cosel (2006) both comment on the considerable variation in shell form observed in some species, L. gagei Oliver and Holmes, 2006a and L. myriamae Cosel, 2006 respectively. This contrasts with the relatively small morphological differences cited for the discrimination of other species, e.g. L. kazani (Salas and Woodside 2002) and L. vestita (Dautzenberg and Fischer 1906 in Cosel 2006). In the latter instances geographic isolation and habitat preferences have played a major role in the in the interpretation of the significance of morphological variation.

\section{Genus Lucinoma Dall, 1901}

Type species. Lucina filosa Stimpson, 1851

Definition. As given by Oliver and Holmes (2006a)

\section{Lucinoma asapheus sp. $\mathrm{n}$.}

urn:Isid:zoobank.org:act:E684B2EE-7C97-4FE9-9445-9B00CFE0259B

http://species-id.net/wiki/Lucinoma_asapheus

Fig. 7

Type material. Holotype; one complete specimen, live collected, TTR 15, stn AT569GR, El Arraiche field, Mercator MV. $35^{\circ} 17.917^{\prime} \mathrm{N}, 06^{\circ} 38.717^{\prime} \mathrm{W}, 358 \mathrm{~m}$, 25 July 2005, NMWZ.2010.4.5.

Paratypes; five specimens, as holotype, NMWZ.2010.4.6. 


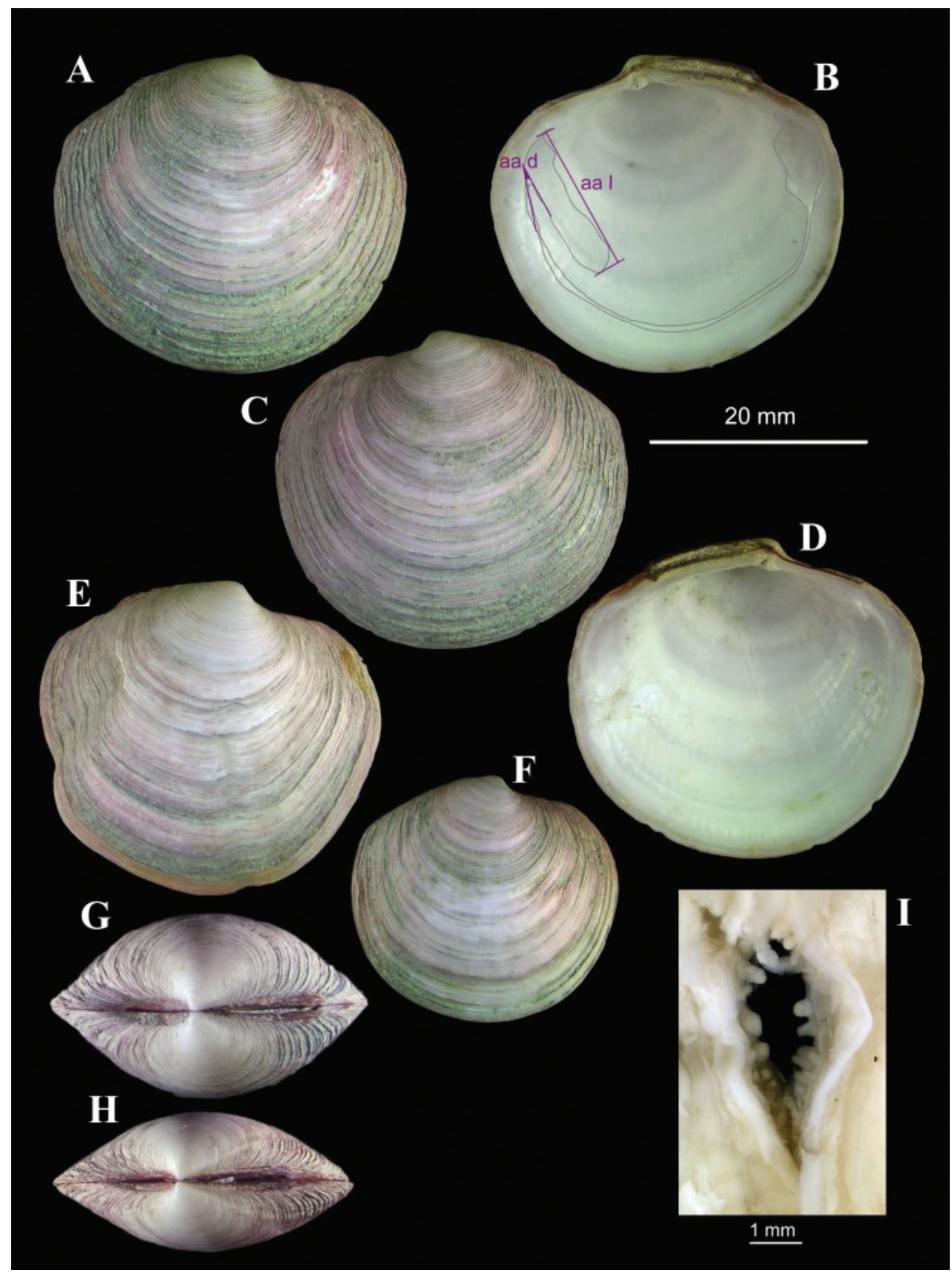

Figure 7. Lucinoma asapheus sp. n. stn. AT569GR, Mercator MV. A-D Holotype, aa d, angle of divergence of anterior adductor scar. aa l, length of anterior adductor scar $\mathbf{E}$ an aberrant specimen $\mathbf{F}$ a small specimen G-H two specimens showing variation in tumidity $\mathbf{I}$ the inhalant siphon. 
Measurements (in mm)

\begin{tabular}{l|c|c|c|c|c|c}
\hline & Length & Height & Width & Anterior scar length & Anterior scar angle & Lunule width \\
\hline Holotype & 33.3 & 30.1 & 15.9 & 15.0 & $15^{\circ}$ & 2.2 \\
\hline Paratype & 25.0 & 23.0 & 10.8 & 11.3 & $17^{\circ}$ & 1.6 \\
\hline Paratype & 30.7 & 27.6 & 18.0 & 14.6 & $16^{\circ}$ & 2.6 \\
\hline Paratype & 28.8 & 27.1 & 13.5 & 13.0 & $15^{\circ}$ & 1.7 \\
\hline Paratype & 32.1 & 29.2 & 16.4 & 16.4 & $18^{\circ}$ & 2.6 \\
\hline Paratype & 31.7 & 29.4 & 15.4 & 16.4 & $15^{\circ}$ & 2.2 \\
\hline
\end{tabular}

Description (Fig. 7). Shell to $34 \mathrm{~mm}$ in length. Solid. Equivalve. Equilateral. Tumidity variable (Fig. 7G, H) but mostly rather compressed. Umbos low, beaks pointing forward. Outline lenticular; posterior dorsal margin almost straight, sloping gently; posterior margin curved but less so than anterior; anterior dorsal margin short, a little concave. Escutcheon narrow, edges slightly raised, extending the length of the posterior dorsal margin; three-quarters filled by ligament, remainder smooth. Lunule distinct, width dependant on tumidity of shell; edges raised, sharp. Sculpture of numerous, low but erect, thin, concentric lamellae; between lamellae are weak concentric lines. Ligament external as a prominent, raised, arched band. Set on a narrow nymph. Hinge weak; two small cardinal teeth in each valve, RV anterior and LV posterior weakly bifid; anterior lateral protuberance distinct to obscure. Pallial line entire. Anterior adductor scar greatly elongate, approximately $3 / 4$ free from pallial line. Shell white, periostracum thin but persistent, straw coloured (all material collected has been stained in Rose Bengal, thus the pink tinge).

The anatomy is essentially that described for $L$. borealis by Allen (1958) and for $L$. kazani by Salas and Woodside (2002). The inhalant siphon is surrounded by numerous short tentacles and papillae (Fig. 7I)

Variation. The shell can be rather compressed (Fig. 7H) or tumid (Fig. 7G) and this may be related to age rather than size as suggested by Oliver and Holmes (2006a) for L. gagei from the Arabian Sea. Some shells also show distortion with radial depressions developing abruptly (Fig. 7E).

Molecular data. Tissues were sent to Dr. John Taylor (NHM, London) for inclusion in his survey of Lucinidae and the $16 \mathrm{~S}$ and CO1 genes were compared with those of Lucinoma borealis. The results although not entirely conclusive indicate that the two populations are not conspecific. More recently, John Taylor's group has demonstrated that $L$. kazani and L. borealis are distinct (J. Taylor pers. comm).

Distribution. Only found live at Mercator MV in the Gulf of Cadiz (358m).

Etymology. asapheus from asaphes Greek: meaning "indistinct" and "baffling", referring to the lack of distinctive morphological characters and the consequent unsettling taxonomic issues.

Remarks. A morphometric analysis was done comparing the Gulf of Cadiz shells with those of $L$. borealis from numerous localities from around the British Isles. This analysis could not demonstrate any statistically valid differences in the outline, the relative size of the anterior adductor scar (aa l on Fig. 7B) or the angle of divergence of this 
scar from the pallial line (aa d on Fig. 7B). It should be noted that the Cadiz sample size was small and that conclusive probability results were unlikely. However, the variation in tumidity and irregularity of some of the Cadiz shells is not found in samples of $L$. borealis. Anatomically $L$. asapheus and $L$. borealis are alike including the papillae that surround the inhalant aperture. Further evidence for the species level distinction between $L$. asapheus and $L$. borealis comes from the molecular data but here again the few specimens available curtails the analysis. Ecologically one might expect mud volcanoes and near shore sulphide enriched sediments to support different species. This argument was used by Salas and Woodside (2002) to support the distinction between $L$. kazani and $L$. borealis, but they also listed some morphological differences and this has been supported by molecular data (J. Taylor pers comm). Some of these, namely the tumidity of the valves, the width of the lunule and the expression of the lateral teeth are found here to be variable and therefore not conclusive. Similar variability was recorded for L. gagei (Oliver and Holmes 2006a) and L. myriamae (Cosel 2006) suggesting that small morphological differences in Lucinoma shells, especially if observed between small samples, may not be reliable taxonomic characters. The papillation of the inhalant siphon does appear to be much less developed in $L$. kazani compared with that in $L$. borealis and $L$. asapheus. The angle of divergence of the anterior adductor scar also shows a difference with that in $L$. kazani having a mean value of ca. $25^{\circ}$ and both $L$. borealis and $L$. asapheus a mean value of ca. $15^{\circ}$. Given that $L$. kazani and $L$. asapheus both inhabit mud volcano settings one might expect them to be conspecific. However, accepting the morphological differences given by Salas \& Woodside between L. kazani and $L$. borealis and that these also hold true for $L$. asapheus then the two must be considered distinct. This may be supported by the wide difference in depth range with $L$. asapheus coming from $358 \mathrm{~m}$ in contrast to L. kazani from $1700-2030 \mathrm{~m}$.

Other Eastern Atlantic species are Lucinoma vestita (Dautzenberg and Fischer 1906) from Cape Verde at $600 \mathrm{~m}$, L. atalantae Cosel, 2006 from Mauritania at c. $2000 \mathrm{~m}$ and L. myriamae Cosel, 2006 from the Angola margin at c. $360 \mathrm{~m}$. Comparisons with $L$. asapheus are as follows. Lucinoma vestita is a smaller species not exceeding $16 \mathrm{~mm}$ in length, more rounded in outline and with a weak sculpture of poorly developed (often absent) comarginal lamellae. Lucinoma atalantae has a distinctly longer and more steeply sloping anterior dorsal margin, a more angular posterior profile and irregular sculpture. Lucinoma myriamae is much larger reaching over $50 \mathrm{~mm}$ in length and has a distinct angular anterior profile; in this respect, it resembles $L$. saldanhae Barnard, 1964 a species not considered by Cosel (2006).

\section{Family Thyasiridae Dall, 1901}

The Thyasiridae of the Gulf of Cadiz were reported on by Rodrigues et al. (2008) and of the seven species recognized only one was closely associated with active mud volcanoes, namely T. vulcolutre Rodrigues \& Oliver, 2008). Here we report upon an additional species to the Gulf of Cadiz from the Captain Arutyunov MV. Since the 
publication of Rodrigues et al. (2008) thyasirids from the Eastern Mediterranean mud volcanoes and the REGAB site off West Africa have become available for study. These species will not be described here but are compared with T. vulcolutre.

\section{Genus Spinaxinus Oliver \& Holmes, 2006b}

Type species. Spinaxinus sentosus Oliver \& Holmes, 2006b

Definition. As given by Oliver and Holmes (2006b)

\section{Spinaxinus cf. sentosus Oliver \& Holmes, 2006b}

http://species-id.net/wiki/Spinaxinus_sentosus

Fig. $8 \mathrm{~A}-\mathrm{D}$

Material examined. One live collected specimen, MSM01.03, Stn 190, deep-water

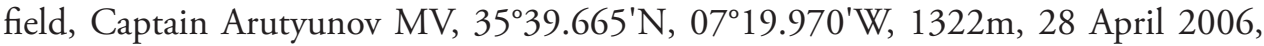
NMWZ.2010.4.7

Description. (Fig. 8A-D). This specimen measures only $2.3 \mathrm{~mm}$ in length and is damaged. The outline agrees with that of $S$. sentosus in being extended anteriorly with a long lunule depression and in the presence of a long but shallow posterior sulcus. These features are in contrast to the juveniles of Thyasira vulcolutre (Rodrigues and Oliver 2008), which also occurs at similar depths and settings.

The periostracal spines are typical of Spinaxinus but are not seen in this specimen. The periostracum is coarse and the vestiges of lamellae and projections can be seen on the extreme edges of the shell especially on the ventral margin.

Remarks. Although the identification is not conclusive the likelihood that this shell is a juvenile Spinaxinus is high and as such represents the first finding of this species in a non-anthropogenic setting. The proximity of the type locality (off northern Portugal) to the Cadiz mud volcanoes makes this supposition more reasonable.

\section{Thyasira vulcolutre Rodrigues \& Oliver, 2008}

http://species-id.net/wiki/Thyasira_vulcolutre

Comments. Thyasira vulcolutre belongs to a group of thyasirids with relatively large shells with weakly defined posterior sulci. It was concluded that it was most similar to T. southwardae (Oliver and Holmes 2006b) from the Anyas Garden site. At that time no thyasirid material had been found at cold seep sites along the West African margin. Consequently, unlike the situation for Lucinoma (Cosel 2006) and Isorropodon (Cosel and Salas 2001, Cosel and Olu 2008) no further biogeographic comparisons could be made. Recently we were able to examine a thyasirid (Fig. $8 \mathrm{E}-\mathrm{F}$ ) from the REGAB site (courtesy of Karine Olu) and although it superficially 


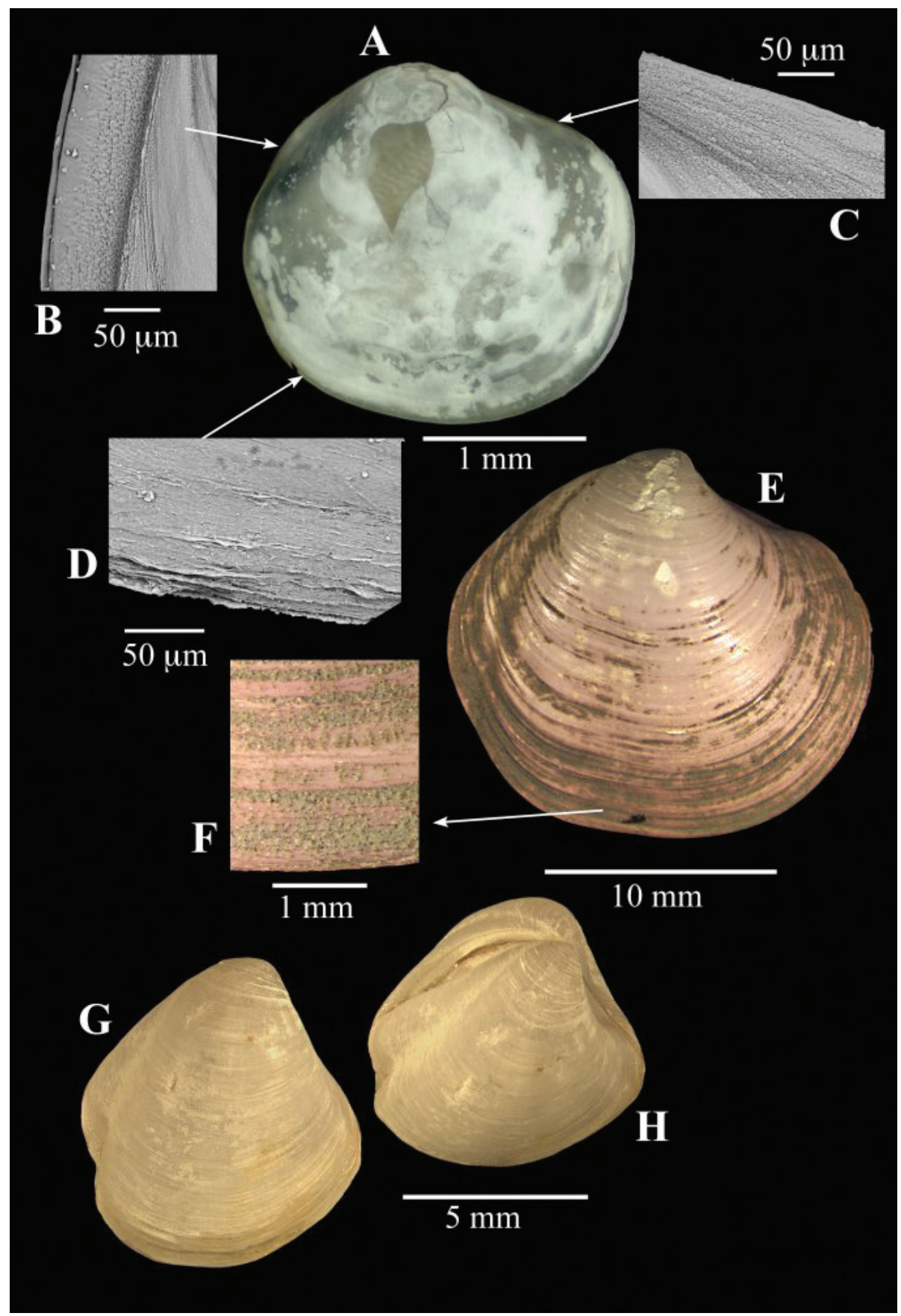

Figure 8. A-D Spinaxinus cf. sentosus Oliver \& Holmes, 2006b. stn. 190, Captain Arutyunov MV. A digital image of right valve B SEM, periostracum on posterior margin C SEM, periostracum on anterior dorsal margin D SEM, periostracum on ventral margin. E-F Thyasira sp., Regab pock mark E external of right valve $\mathbf{F}$ periostracum. G-H Thyasira striata, Sturany, MEDINAUT, Eastern Mediterranean $\mathbf{G}$ external of right valve $\mathbf{H}$ oblique view showing posterior sulci. 
resembles $T$. vulcolutre it significantly differs in having a minutely spicate periostracum (Oliver in prep).

Thyasira striata Sturany, 1896 has long been known from deep water in the eastern Mediterranean but was recently re-discovered at cold seep sites (Olu-Le Roy et al. 2004). Small specimens resemble T. flexuosa but larger examples (Fig. 8G-H) are very tumid with prominent lunule and deep posterior sulci quite unlike T. vulcolutre.

These new data suggest that those thyasirids closely associated with active cold seeps have restricted ranges within the eastern Atlantic/Mediterranean region.

\section{Superfamily Glossoidea Gray, 1847 Family Vesicomyidae Dall \& Simpson, 1901}

The family Vesicomyidae has become familiar as a group of large chemosymbiotic clams associated with hot vents (Boss and Turner 1980, Tunnicliffe 1991) and cold seeps (Turner 1985, Okutani and Métivier 1986) and exemplified by Calyptogena magnifica Boss and Turner 1980. Not all taxa are large and the smallest, such as Vesicomya atlantica, are probably not chemosymbiotic (Allen 2001). Despite their conspicuous presence in many reducing environments, the taxonomy of vesicomyids is far from being settled, at both the species and supraspecific levels (Krylova and Sahling 2006). Different authors estimate that the family includes from 50 to more than 70 recent and fossil species and new species are constantly erected (Cosel and Salas 2001, Krylova and Sahling 2006, Krylova and Janssen 2006, Cosel and Olu 2009, Krylova et al. 2010). To date, fifteen chemosymbiotic species in the genera Waisiuconcha, Isorropodon, Callogonia, Wareniconcha, Elenaconcha, Calyptogena, Christineconcha, Laubiericoncha and Abyssogena have been reported from the eastern Atlantic (Krylova and Sahling 2010).

\section{Genus Isorropodon Sturany, 1896}

Type species. Isorropodon perplexum Sturany, 1896

Definition. As given by Cosel and Salas (2001)

\section{Isorropodon megadesmus sp. $\mathbf{n}$.}

urn:lsid:zoobank.org:act:317BA11E-0B29-4396-8696-DEDCAF00B29F http://species-id.net/wiki/Isorropodon_megadesmus

Figs 9, 10C-D

Material examined. Holotype: one complete specimen, live collected, MSM01.03, stn 218, deep-water field, Captain Arutyunov MV. 35³9.642' N, 07²0.049'W, $1321 \mathrm{~m}$, 30 April 2006, NMWZ.2010.4.8. 


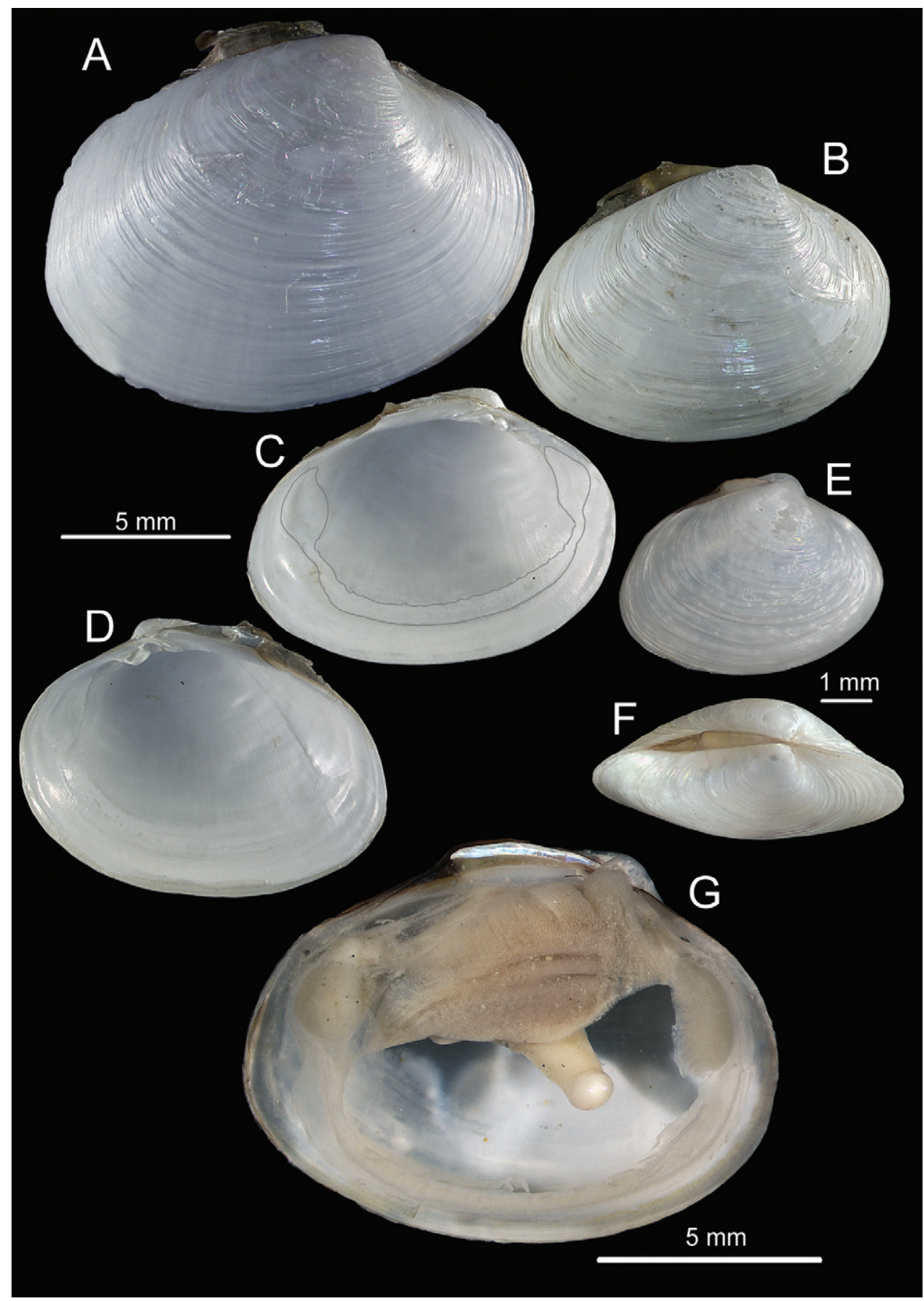

Figure 9. Isorropodon megadesmus sp. n. stn. 218, Captain Arutyunov MV. A large right valve, paratype B-D holotype, right valve external, left valve internal, right valve internal $\mathbf{E}$ small right valve, paratype F dorsal view, paratype $\mathbf{G}$ gross anatomy viewed after removal of right valve and mantle. 


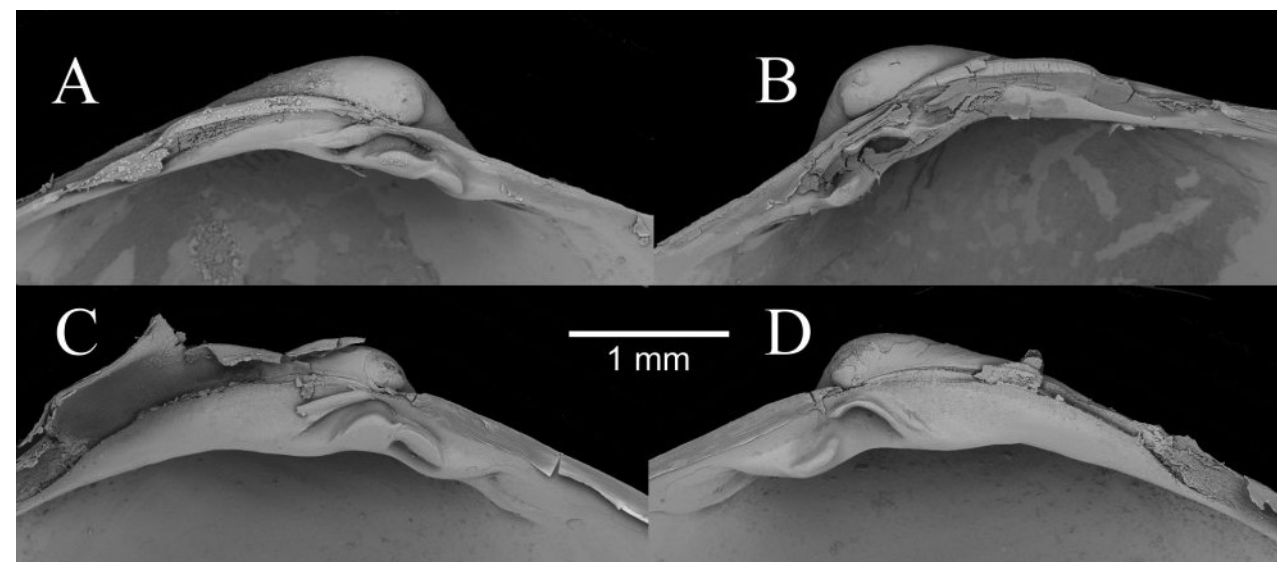

Figure I0. Comparison between the hinge teeth of Isorropodon sp. indet. (A, B) and Isorropodon megadesmus sp. n. (C, D).

Paratypes: ten specimens, four shells and one valve, same data as holotype, NMWZ.2010.4.9.

Other material examined: over thirty decalcified juvenile specimens, MSM01.03, stn 218, deep-water field, Captain Arutyunov MV. 35³9.642'N, 07²0.049'W, $1321 \mathrm{~m}$, 30 April 2006; one specimen, MSM01.03, stn 225, same locality, 35³9.707'N, $07^{\circ} 20.020^{\prime} \mathrm{W}, 1322 \mathrm{~m}, 4$ May 2006.

Measurements (in mm)

\begin{tabular}{l|c|c|c|c}
\hline & Length & Height & $\begin{array}{c}\text { Tumidity } \\
\text { One valve (paired) }\end{array}$ & Ratio (L/T) \\
\hline Holotype & 11.2 & 8.2 & $2.3(4.6)$ & 2.4 \\
\hline Paratype & 14.8 & 11.5 & $3.25(6.5)$ & 2.3 \\
\hline Paratype & 10.6 & 7.7 & $2.3(4.6)$ & 2.3 \\
\hline Paratype & 6.2 & 4.4 & $1.3(2.6)$ & 2.4 \\
\hline Paratype & 6.6 & 4.5 & $1.3(2.6)$ & 2.5 \\
\hline Paratype & 9.1 & 6.4 & $1.85(3.7)$ & 2.5 \\
\hline Paratype & 9.6 & 7.2 & incomplete & \\
\hline
\end{tabular}

Description. (Figs 9, 10C-D). To $15 \mathrm{~mm}$ in length. Thin. Equivalve. Inequilateral, beaks in front of the midline. Compressed, length to tumidity ratio 2.3 to 2.5. Outline subovate, anterior rounded, posterior a little obliquely truncated; ventral curvature at its maximum well to the posterior of the mid line. Lunule indistinct, not depressed. Escutcheon narrow, deeply excavated but entirely occupied by ligament. Sculpture of dense concentric lines and irregular growth stops or wrinkles. Hinge plate prominent dominated by a long nymph supporting a very large external ligament; ligament rises well above the dorsal margin of the shell and extends posteriorly beyond the nymph to fill the escutcheon. Hinge teeth complex; RV with a single prominent anterior lateral tooth situated in front of the beak in the form of a narrow projecting peg with a flat or slightly excavated dorsal surface; below the beak is an arched laminar tooth its 
anterior end overlapping the lateral tooth, its posterior slopes steeply and ventrally and merges with a second ridge only noticeable by a weak notch mid way on this combined ridge. $\mathrm{LV}$ with a thin laminar posterior cardinal angled obliquely plus two combined cardinals in a horizontal orientation the posterior part larger than the anterior with a distinct notch between the two parts. Pallial line entire with a very small straightened section below the posterior adductor scar; adductor scars of about equal size; anterior pedal retractor scar deeply impressed, situated immediately in front of the hinge plate. Periostracum thin, persistent, glossy. Shell white.

Mantle thin, mantle edge unfused except for short inhalant and exhalant siphonal apertures; inhalant aperture with many papillae increasing in size dorsally, exhalant with papillae of equal size. Foot with a distinct finger-like toe and poorly developed heel, pedal retractors prominent, the anterior attached in a deep impression close to the hinge. Anterior adductor muscle oval in cross-section, posterior adductor muscle subcircular, smaller than the anterior one. Ctenidia of a large, single (inner) demibranch, ascending part approximately one half the height of the outer, filaments fine tightly connected.

Distribution. Isorropodon megadesmus is restricted to Captain Arutyunov MV (1321-1322m).

Etymology. megadesmus from the Greek mega meaning large and desma meaning bond; referring to the external ligament.

Remarks. The taxonomy of Isorropodon in the Atlantic and Mediterranean is complex and potentially confused (Cosel and Salas 2001, Cosel and Olu 2009). Cosel and Salas (2001) described two new species from the Eastern Atlantic, namely I. bigoti and I. curtum. They transferred a third from Kelliella, namely I. elongatum (Allen 2001). In discussing, the Mediterranean, I. perplexum Cosel and Salas (2001) stated that Isorropodon species are variable with regard to outline, tumidity and development of hinge teeth and this is illustrated in their figures 36-47 for I. perplexum. They noted similarities in shell morphology between the Eastern Mediterranean species I. perplexum and the West African I. bigoti but suggested that these taxa were isolated geographically and doubtfully could have gene flow between them. They further supported this argument by stating that $I$. perplexum had not been found in the Western Mediterranean or Ibero-Moroccan Gulf. In 2009, Cosel and Olu described another Isorropodon from West Africa (I. atalantae) and placed another vesicomyid in this genus (I. striatum Thiele and Jaeckel 1931). Therefore, before the discovery of Isorropodon in the Gulf of Cadiz there were already five west African species and one from the eastern Mediterranean. With the discovery of Isorropodon at the Capt. Arutyunov MV the assertion made by Cosel and Salas (2001) on genetic isolation can be questioned, as there is the possibility of gene flow between the seeps in the Mediterranean and around the east African coast.

In contrast to the variability given by Cosel and Salas (2001) for I. perplexum, all of the shells from station 218 examined here are constant with regard to features of outline, tumidity and hinge teeth. However, a single shell from station 180 is distinct, being inflated, having a distinct lunule, having a much smaller ligament and in the ventral margin being more convex. The shells from station 218 are distinct from all 
the shells of I. perplexum figured by Cosel and Salas (2001) in having a much longer nymph with the posterior teeth reaching only about one third of the ligament as opposed to the half distance given for I. perplexum by Cosel and Salas (2001). Furthermore, most of the shells illustrated by them have a more convex ventral margin than the shells from station 218 . The single shell from station 180 shares more features with the Mediterranean shells in having the small ligament, convex ventral margin and being more inflated.

The outline of I. bigoti differs from all of the above in the narrower anterior and distinct angulation of the ventral curve, but is has a short nymph similar to $I$. perplexum and the shell from station 180 .

Isorropodon atalantae has a more sunken lunule and more angular posterior profile than either of the Gulf of Cadiz taxa. Isorropodon curtum Cosel and Salas, 2001, from off Mauritania, is more circular in outline and I striatum Thiele and Jaeckel, 1931 from off Angola, is a much larger and more elongate form.

Cosel and Salas (2001) reassigned Kelliella elongata Allen, 2001 to the genus Isorropodon. Following examination of the type material in the Natural History Museum, London (BMNH 1998180) we conclude that it is not conspecific with any of the taxa discussed here. It is a small species not exceeding $2 \mathrm{~mm}$ in any of the over 300 specimens listed by Allen (2001). It is inflated with a distinct lunule but the demarcating line illustrated by Allen (2001) is not so apparent. The hinge of the right valve has three distinct teeth including a small posterior tooth (4b in Allen 2001), which is not present in either of the species from the Cadiz mud volcanoes. Furthermore, the ligament is small and does not project as in I. megadesmus. From the ctenidial anatomy there is no indication that this species is chemosymbiotic. In addition to the morphological differences, I. elongatum has been collected from a wide geographical range, wide bathymetric range and associated with the typical oligotrophic deep-sea bivalve assemblage (derived from Allen 2008). It would appear that I. elongatum, if a chemosymbiotic species is not confined to seep/vent settings but as stated by Allen (2001) it is absent from the European basin and it was not present in the samples taken in the Gulf of Cadiz away from the vicinity of the mud volcanoes (Rodrigues 2009).

\section{Isorropodon sp indet}

Figs 10A-B, 11

Material examined. One complete specimen, live collected, MSM01.03, stn 180, deep-water field, Captain Arutyunov MV. 35³9.740'N, 07¹9.960'W, 1323m, 27 April 2006, NMWZ.2010.4.10.

Measurements. $6.4 \mathrm{~mm}(\mathrm{~L}) \times 5.3 \mathrm{~mm}(\mathrm{H}) \times 3.6 \mathrm{~mm}(\mathrm{~T})$

Description (Figs 10A-B, 11). $6.4 \mathrm{~mm}$ in length. Thin. Equivalve. Inequilateral, beaks in front of the midline. Inflated, length to tumidity ratio $=1.8$. Outline subovate, anterior bluntly rounded, posterior a little obliquely truncated; ventral curvature at its maximum more or less at the midline. Lunule indistinct, slightly depressed. Es- 


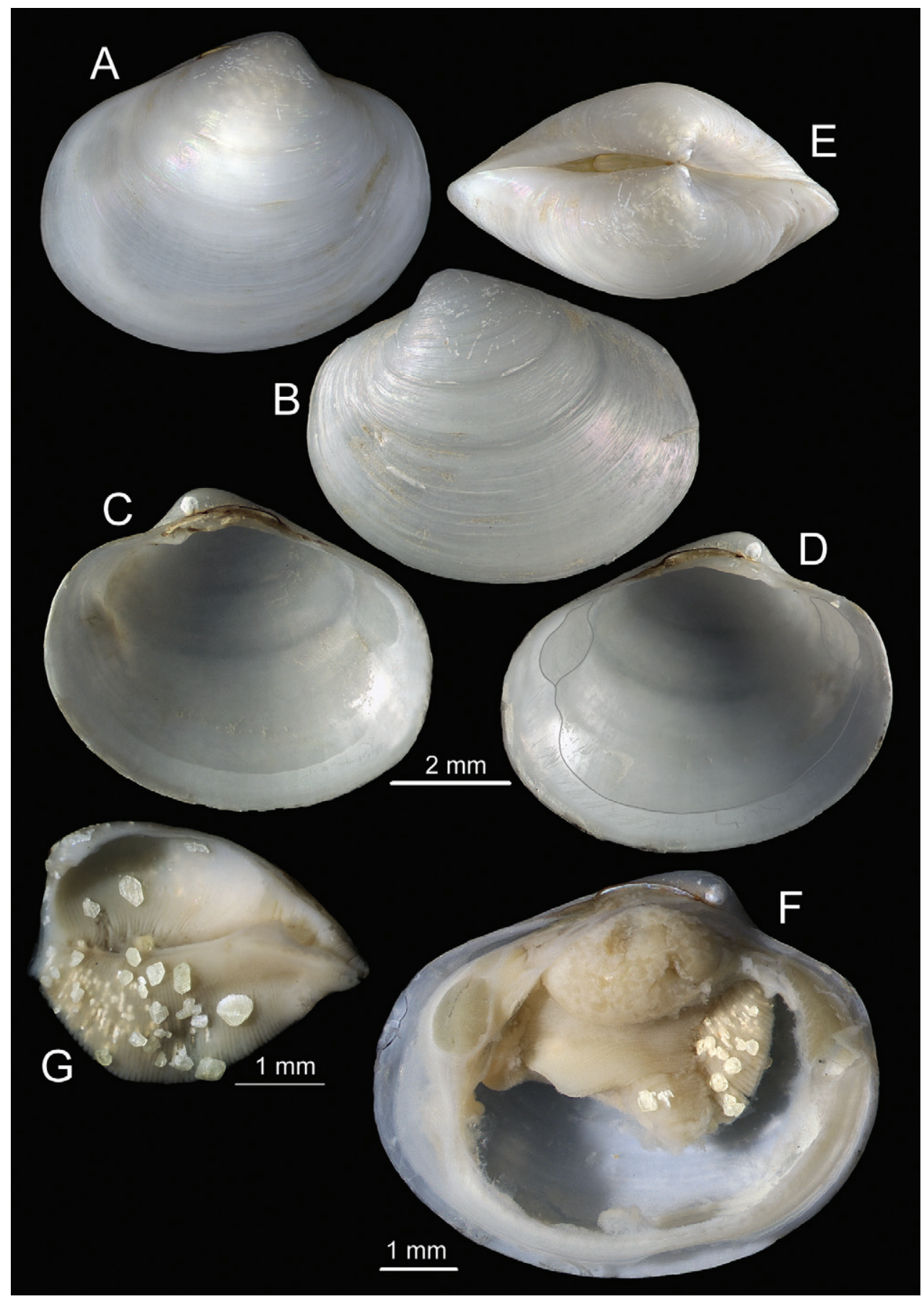

Figure II. Isorropodon sp. indet., stn. 180 Captain Arutyunov MV. A-D External and internal views of right and left valves $\mathbf{E}$ dorsal view $\mathbf{F}$ gross anatomy viewed after removal of right valve and mantle $\mathbf{G}$ Excised ctenidium with crystalline artifacts. 
cutcheon narrow, deeply excavated. Sculpture of dense, concentric, fine lines and few irregular growth stops. Hinge plate narrow, nymph supporting an external ligament; ligament scarcely rises above the dorsal margin of the shell and extends posteriorly to half the length of the escutcheon. Hinge teeth complex; RV with a single prominent anterior lateral tooth situated in front of the beak in the form of a narrow projecting peg with a flat or slightly excavated dorsal surface; below the beak is weakly arched laminar tooth its anterior end overlapping the lateral tooth, its posterior slopes steeply and ventrally and merges with a second ridge only noticeable by a weak notch mid way on this combined ridge. LV with a thin laminar posterior cardinal angled obliquely plus two combined cardinals in a horizontal orientation the posterior part only slightly larger than the anterior with a distinct notch between the two parts. Pallial line entire with a very small straightened section below the posterior adductor scar; adductor scars of about equal size; anterior pedal retractor scar deeply impressed, situated immediately in front of the hinge plate. Periostracum thin, persistent, glossy. Shell white

Mantle thin, mantle edge unfused except for short inhalant and exhalant siphonal apertures; inhalant aperture with few papillae increasing in size dorsally, the latter as short tentacles, exhalant with papillae of equal size. Foot with a blunt finger-like toe and poorly developed heel, pedal retractors prominent, the anterior attached in a deep impression close to the hinge. Anterior adductor muscle pyriform in cross-section, posterior adductor muscle subcircular, smaller than the anterior one. Ctenidia of a large, single (inner) demibranch, filling the majority of the mantle cavity, ascending part approximately one half the height of the outer, filaments fine tightly connected.

The numerous crystalline growths seen on and between the filaments are believed to be natural and not an artifact of preservation.

Distribution. Isorropodon sp indet is restricted to Captain Arutyunov MV (1323m).

Remarks. As discussed above for I. megadesmus.

\section{Ecological Discussion}

Symbiosis. Twelve bivalve species have been found in close association with chemosynthetic settings in the Gulf of Cadiz (this paper; Génio et al. 2008, Rodrigues et al. 2008, Rodrigues et al. 2010) with a thirteenth, Callogonia cyrili Cosel and Salas probable but not proven (Cosel and Salas 2001). The trophic status of these Solemyidae, Lucinidae, Thyasiridae and Vesicomyidae species has been confirmed by their gross anatomical features (e.g. gills for thyasirids, reduced gut for solemyids) and, in some cases, also by stable isotope analysis and/or molecular analysis (Rodrigues et al. 2010, Rodrigues and Duperron 2011). The $\delta^{13} \mathrm{C}$ values for solemyids (Acharax gadirae, Solemya (Petrasma) elarraichensis), lucinid (Lucinoma asapheus) and thyasirid (Thyasira vulcolutre) bivalves were found to be in line with data for other bivalves known to host thiotrophic symbionts (Fisher 1990, Carlier et al. 2010). On the other hand, ${ }^{13} \mathrm{C}$ and $\delta^{34} \mathrm{~S}$ values for the bathymodiolid species (Bathymodiolus mauritanicus) 
were compatible with the predominance of methanotrophy. Phylogenetic analysis of bacterial 16S rRNA gene sequences demonstrated that most bacteria were related to known sulfide-oxidizing endosymbionts found in other deep-sea chemosynthetic environments, with the co-occurrence of methane-oxidizing symbionts in Bathymodiolus specimens. The molecular results confirmed the thiotrophic nutrition for $S$. ( $P$.) elarraichensis, A. gadirae, L. asapheus and T. vulcolutre and a dual symbiosis for B. mauritanicus (Rodrigues et al. 2010). Nutrition of Isorropodon megadesmus was not yet confirmed by either isotopic or molecular analyses but other studies suggest that Isorropodon perplexum contain sulphur-oxidizing bacteria (Olu-Le Roy et al. 2004), a phylotype also present in Spinaxinus sentosus (Oliver and Holmes 2006b).

Distribution patterns. The Gulf of Cadiz mud volcano field is comprised of over thirty seeps of various activity and spread over a bathymetric range of $200-4000 \mathrm{~m}$. Of the 25 mud volcanoes sampled, 13 have chemosymbiotic species, which indicates their importance in the structure of the seep assemblages (Fig. 1). Most of the thirteen, chemosymbiotic, species found in the Gulf of Cadiz are restricted to one or two mud volcanoes. This patchy distribution can result from physical or physiological constraints such as depth, distance and fluid flow rates. They were more frequent in the shallower mud volcanoes (200-1500m) but were especially diverse in Captain Arutyunov MV where five different species co-occur (Fig. 1). Some taxa are confined to single mud volcanoes whereas others are more widespread.

The family most frequently encountered in the chemosynthesis-based assemblages of the mud volcanoes from the Gulf of Cadiz, is the Solemyidae. The family is represented by two genera, Solemya (Petrasma) with a shallower distribution (358-1030m) and Acharax with a deeper distribution (556-3902m) but co-occurring at intermediate depths in the Western Moroccan field. Co-occurrence of these genera has not been reported elsewhere and may be explained by the apparent absence of the subgenus Petrasma from seep settings preferring reducing sediments and low oxygen conditions (Kamenev 2009).

This is the first record of this family in cold seeps from the North-east Atlantic, although Solemya (Solemya) togata is well known from shallow settings such as sea-grass beds in the Mediterranean. Why this species has not or been unable to colonize the shallow mud volcanoes is unknown. In contrast, the Pacific Solemya (S.) tagiri Okutani et al. (2003) is thought to be associated with seep settings (Kamenev 2009) suggesting that habitat is not linked to phylogeny.

Unlike Solemya (Petrasma), Acharax species are consistently associated with seep or vent settings and some species such as the Pacific A. johnsoni have extensive bathymetric ranges from 100 to over 5000m (Kamenev 2009). Acharax species are all rather morphologically similar and given the molecular data given by Neulinger et al. (2006) it may be found that there are more species than currently recognized. This is suggested here by the morphological differences in the posterior aperture between the shallow and deeper specimens. Some Acharax specimens (from Yuma, Ginsburg and Jesus Baraza MVs) host commensal polychaetes (Ravara et al. 2007).

In contrast to the solemyids, the lucinid Lucinoma asapheus has only been collected at Mercator MV, although video observations revealed presence of lucinids in other 
mud volcanoes from the Spanish field (MR Cunha, pers. comm.). Lucinoma asapheus is very similar morphologically to Lucinoma kazani from the Eastern Mediterranean (Salas and Woodside 2002) and both are almost identical with the widespread shelf species Lucinoma borealis that is abundant in the North-east Atlantic. Our preliminary molecular data separated Lucinoma borealis from $L$. asapheus, and further work on $L$. kazani confirms that it is also distinct from $L$. borealis (J Taylor, pers comm.). A more detailed study including a wider data set from $L$. asapheus should elucidate the relationship between it and L. kazani. The three species so far mentioned are similar but quite distinct from the much larger, deeper water SE Atlantic species such as L. myriamae and $L$. saldanhae and the Indo-Pacific species, L. gagei and L. yoshidai (Oliver and Holmes 2006a). It is therefore plausible that L. asapheus, L. kazani and L. borealis are a clade, but we cannot ascertain their sequence of appearance. Are the mud volcano species independently evolved from shallow water ancestors or are they descended from a common seep dwelling stock?

The thyasirid Thyasira vulcolutre was only found in the deep-water mud volcano field (Rodrigues et al. 2008). Despite the high number of thyasirid species present in the Gulf of Cadiz (eight) only one Thyasira vulcolutre is strictly associated with active mud volcanoes (Rodrigues et al. 2008). Spinaxinus sentosus has been discovered in the organic cargo of a sunken ship in the Atlantic Ocean (Oliver and Holmes 2006b) and is reported here for the first time associated to a cold seep site. Other chemosymbiotic thyasirids (Table 1) were found associated with Siboglinidae fields from the HakonMoseby MV (Gebruk et al. 2003) and from the eastern Mediterranean mud volcanoes (Olu-Le Roy et al. 2004).

Small vesicomyids including Isorropodon megadesmus and Isorropodon sp. were very abundant in Captain Arutyunov MV. The species I. perplexum is known only from the Eastern Mediterranean (Table 1), and was shown to harbour sulphur-oxidizing bacteria (Salas and Woodside 2002). During TTR17 (2008) a living specimen of Calyptogena was found for the first time in the Gulf of Cadiz. The specimen collected from Bonjardim has been identified as belonging to the species Christineconcha regab Cosel and Olu, 2009, recently found in the Regab region (E Krylova, pers. comm.). Other large vesicomyid shells but no living specimens of Laubiericoncha chuni (Thiele and Jaeckel 1931) and Pliocardia sp. were also collected at the same mud volcano. The vesicomyids C. regab and L. chuni dominate the faunal assemblages of Congo and Angola Basin cold seeps (Olu-Le Roy et al. 2007, Cosel and Olu 2008).

Bathymodioline mussels of the amphi-Atlantic species Bathymodiolus mauritanicus were only found living in Darwin MV although extensive graveyards of mussel shell ash are also found in other mud volcanoes of the western Moroccan field (Génio et al. 2008). Although confirmed as chemosymbiotic, Bathymodiolus mauritanicus was first collected during a commercial trawl in the Mauritanian margin where no hydrocarbon seeps have yet been discovered. Nevertheless owing to the repeated appearance of other typical seep molluscs it is likely the existence of seepage in this region might be confirmed in the future (Cosel 2002). Another small mytilid Idas sp. was collected living in a small wood fall retrieved by the ROV Isis at Carlos Ribeiro MV during JC10. Idas 
Table I. Distribution of chemosymbiotic taxa known from seep/mud volcano fields in the Eastern Atlantic and Mediterranean.

\begin{tabular}{|c|c|c|c|c|}
\hline Taxon & \begin{tabular}{c|} 
East. \\
Mediterranean \\
\end{tabular} & $\begin{array}{c}\text { Gulf } \\
\text { of Cadiz }\end{array}$ & $\begin{array}{c}\text { Mauritania } \\
\text { Basin }\end{array}$ & $\begin{array}{l}\text { Gulf of } \\
\text { Guinea }\end{array}$ \\
\hline \multicolumn{5}{|l|}{ Solemyidae } \\
\hline Acharax indet. & & & & $\mathbf{X}$ \\
\hline Acharax gadirae & & $\mathbf{X}$ & & \\
\hline Solemya (Petrasma) elarraichensis & & $\mathbf{X}$ & & \\
\hline Solemyidae Eastern Med & $\mathbf{X}$ & & & \\
\hline \multicolumn{5}{|l|}{ Mytilidae } \\
\hline Bathymodiolus mauritanicus & & $\mathbf{X}$ & $\mathbf{X}$ & \\
\hline B. aff. boomerang & & & & $\mathbf{X}$ \\
\hline Idas modiolaeformis & $\mathbf{X}$ & & & \\
\hline Idas sp. & $\mathbf{X}$ & $\mathbf{X}$ & & \\
\hline \multicolumn{5}{|l|}{ Lucinidae } \\
\hline Lucinoma asapheus & & $\mathbf{X}$ & & \\
\hline Lucinoma kazani & $\mathbf{X}$ & & & \\
\hline Lucinoma atalantae & & & $\mathbf{X}$ & \\
\hline Lucinoma myriamae & & & & $\mathbf{X}$ \\
\hline Myrtea amorpha & $\mathbf{X}$ & & & \\
\hline Graecina karinae & & & & $\mathbf{X}$ \\
\hline Joellina dosiniformis & & & & $\mathbf{X}$ \\
\hline \multicolumn{5}{|l|}{ Thyasiridae } \\
\hline Thyasira vulcolutre & & $\mathbf{X}$ & & \\
\hline T. striata & $\mathbf{X}$ & & & \\
\hline T. sp. n. & & & & $\mathbf{X}$ \\
\hline Spinaxinus sentosus & & $\mathbf{X}$ & & \\
\hline \multicolumn{5}{|l|}{ Vesicomyidae } \\
\hline Isorropodon perplexum & $\mathbf{X}$ & $\mathbf{X}$ ? & & \\
\hline I. megadesmus & & $\mathbf{X}$ & & \\
\hline I. bigoti & & & $\mathbf{X}$ & $\mathbf{X}$ \\
\hline I. curtum & & & $\mathbf{X}$ & \\
\hline I. striatum & & & & $\mathbf{X}$ \\
\hline I. atalantae & & & & $\mathbf{X}$ \\
\hline Callogonia cyrili & & $\mathbf{X}$ & & \\
\hline C. mauritanica & & & $\mathbf{X}$ & \\
\hline Calyptogena valdiviae & & & $\mathbf{X}$ & $\mathbf{X}$ \\
\hline Christineconcha regab & & $\mathbf{X}$ ? & & $\mathbf{X}$ \\
\hline Wareniconcha guineensis & & & & $\mathbf{X}$ \\
\hline Elenaconcha guiness & & & & $\mathbf{X}$ \\
\hline Laubiericoncha chuni & & $\mathbf{X}$ ? & & $\mathbf{X}$ \\
\hline Pliocardia sp. & & $\mathbf{X}$ & & \\
\hline Abyssogena southwardae & & & $\mathbf{X}$ & \\
\hline $\begin{array}{l}\text { Totals } \\
\text { () shared species }\end{array}$ & $\mathbf{6}(1 ?)(0)(0)$ & (1?) $\mathbf{1 3}$ (1) (2) & (0) (1) 7 (2) & (0) (1) (2) 14 \\
\hline
\end{tabular}


specimens are present in the mud volcanoes from the Eastern Mediterranean (Table 1) and their symbioses have been studied in detail by Duperron et al. (2008).

When discussing Isorropodon, Cosel and Salas (2001) suggested that Mediterranean and SE Atlantic forms were unlikely to be the same species due to their geographic isolation. With the discovery of Isorropodon in the Gulf of Cadiz, this argument can be challenged. Here we review the distributions of all chemosymbiotic taxa found at seeps in the Eastern Atlantic/Eastern Mediterranean and consider the apparent levels of endemism. Table 1 presents the known taxa and their occurrence in the four major seep fields, namely Eastern Mediterranean, Gulf of Cadiz, off Mauritania and the Gulf of Guinea.

The Gulfs of Cadiz and Guinea are most diverse and almost equally so with 13 and 14 species respectively. The less sampled Mauritania basin has only 7 recorded species while the well studied Eastern Mediterranean has only 6 species. The number of species common to more than two fields is zero and the maximum number of shared species is two, that for the Gulfs of Cadiz and Guinea. These data suggest high levels of endemism within fields but where there is overlap, especially with the larger vesicomyids, that this occurs at deeper sites. The vesicomyids are the most diverse family but only one species has colonized the Eastern Mediterranean and they appear to be rare in the Gulf of Cadiz compared with the Gulf of Guinea. From a geological history perspective one can explain the poor diversity in the Eastern Mediterranean from the shorter period of time for colonization since the re-invasion of Atlantic waters post the hypersaline event. At this time there is no evidence to indicate the origins of the Eastern Atlantic faunas, either by dispersal or local speciation. Molecular data from the species rich genus Isorropodon may illuminate the relationships and sequence of speciation and we await the study in progress on the Vesicomyidae mentioned by Cosel and Olu (2008). Warén and Bouchet (2009) in discussing seep gastropods stated that the West African fauna was quite distinct from that of the Gulf of Cadiz at both species and generic levels and suggested that the latter was of more recent origin via local radiation. At the generic level, these findings appear at odds with the bivalve data where there are strong similarities between the Gulfs of Guinea and Cadiz. The exceptions are Solemya (Petrasma), which appears to have a NW Atlantic origin and Lucinoma species, where their origin may be local.

Warén and Bouchet (2009) further indicated strong affinities of the West African fauna with the Western Atlantic and Gulf of Mexico faunas. Relationships among the bivalves with the western Atlantic at the species level are few, if any; only with Bathymodiolus mauritanicus is there a suggestion of an amphi-Atlantic distribution (Génio et al. 2008). At the generic level there is considerable over-lap within the solemyids, lucinids and thyasirids but less so with the vesicomyids. This may be in part to the considerable number of new genera erected for eastern Atlantic taxa by Cosel and Olu (2008, 2009). 


\section{Acknowledgements}

Thanks are due to the co-chief-scientists Luís Pinheiro (Departamento de Geociências, Universidade de Aveiro) and Michael Ivanov (Moscow State University) for the invitation to participate in the TTR cruises (Training Through Research Programme, IOC-UNESCO), Henk de Haas (chief-scientist of the Microsystems 2007) and to Olaf Pfannkuche (chief-scientist of the MSM01-03. IFMGEOMAR).

This research was partially supported by the HERMES project (European Commission's Sixth Framework Programme under the priority "Sustainable Development, Global Change and Ecosystems", EC contract GOCE-CT-2005-511234) and is a contribution to the project HERMIONE (European Commission's Framework Seven Programme, contract number 226354).

The second author was supported by a PhD grant (SFRH/BD/17085/2004) from Fundação para a Ciência e Tecnologia.

We also wish to thank John Taylor (Natural History Museum, London) for his helpful discussion on many aspects of this paper and to Elena Krylova (P.P. Shirshov Institute of Oceanology) for information on the Vesicomyidae.

\section{References}

Abbott RT (1974) American Seashells; the marine Mollusca of the Atlantic and Pacific Coasts of North. America. Van Nostrand Reinhold, New York, 663 pp.

Akhmetzhanov AM, Ivanov MK, Kenyon NH, Mazzini A (Eds) (2007) Deep water cold seeps, sedimentary environments and ecosystems of the Black and Tyrrhenian Seas and the Gulf of Cadiz. Preliminary results of investigations during the TTR-15 cruise of RV Professor Logachev, June-August, 2005. IOC Technical Series, 72.

Akhmetzhanov AM, Ivanov MK, Kenyon NH, Mazzini A (Eds) (2008) Deep water depositional systems and cold seeps of the Western Mediterranean, Gulf of Cadiz and Norwegian continental margins. Preliminary results of investigations during the TTR-16 cruise of RV Professor Logachev, May-July, 2006. IOC Technical Series, 76: 58 pp + Annexes.

Allen JA (1958) On the basic form and adaptations to habitat in the Lucinacea (Eulamellibranchia). Philosophical Transactions of the Royal Society B, 241: 421-484. doi:10.1098/ rstb. 1958.0010

Allen JA (2001) The family Kelliellidae (Bivalvia: Heterodonta) from the deep Atlantic and its relationship with the family Vesicomyidae. Zoological Journal of the Linnean Society 131: 199-226.

Allen JA (2008) Bivalvia of the Deep Atlantic. Malacologia 50(1-2): 57-173. doi:10.1111/j.1096-3642.2001.tb01315.x

Barnard KH (1964) Contributions to the knowledge of South African marine Mollusca. Part V. Lamellibranchiata. Annals of the South African Museum 47:361-593. doi:10.4002/00762997-50.1.57

Boss KJ, Turner RD (1980) The giant white clam from the Galapagos Rift, Calyptogena magnifica species novum. Malacologia 20: 161-194. 
Carlier A, Ritt B, Rodrigues CF, Olu K, Sarrazin J, Grall J, Clavier J (2010) Heterogeneous energetic pathway and carbon sources for deep eastern Mediterranean cold-seep communities. Marine Biology 157(11): 2545-2565. doi:10.1007/s00227-010-1518-1

Carney RS (1994) Consideration of the oasis analogy for chemosynthetic communities at Gulf of Mexico hydrocarbon vents. Geo-Marine Letters 14: 149-159. doi:10.1007/BF01203726

Conway NM, Howes BL, McDowell Capuzzo JE, Turner RD, Cavanaugh CM (1992) Characterization and site description of Solemya borealis (Bivalvia: Solemyidae), another bivalvebacteria symbiosis. Marine Biology 112: 601-613. doi:10.1007/BF00346178

Cosel R von (2002) A new species of bathymodioline mussel (Mollusca, Bivalvia, Mytilidae) from Mauritania (West Africa) with comments on the genus Bathymodiolus Kenk and Wilson, 1985. Zoosystema 24(2): 259-271.

Cosel R von (2006) Taxonomy of tropical West African bivalves. VI. Remarks on Lucinidae (Mollusca: Bivalvia), with descriptions of six new genera and eight new species. Zoosystema 28(4): 805-851.

Cosel R. von, Bouchet P (2008) Tropical deep-water lucinids (Mollusca: Bivalvia) from the Indo-Pacific: essentially unknown, but diverse and occasionally gigantic. In: Héros V, Cowie R, Bouchet P (Eds) Tropical Deep Sea Benthos, volume 25. Mémoires du Muséum National d'Histoire Naturelle 196: 115-21.

Cosel R von, Salas C (2001) Vesicomyidae (Mollusca: Bivalvia) of the genera Vesicomya, Waisiuconcha, Isorropodon and Callogonia in the eastern Atlantic and Mediterranean. Sarsia 86: 333-366.

Cosel R von, Olu K (2008) A new genus and new species of Vesicomyidae (Mollusca, Bivalvia) from cold seeps on the Barbados accretionary prism, with comments on other species. Zoosystema 30(4): 924-944.

Cosel R von, Olu K (2009) Large Vesicomyidae (Mollusca: Bivalvia) from cold seeps in the Gulf of Guinea off the coasts of Gabon, Congo and northern Angola. Deep Sea Research Part II: Topical Studies in Oceanography 56 (23): 2350-2379. doi:10.1016/j.dsr2.2009.04.016

Dall WH (1891) On some new or interesting West American shells obtained from the dredgings of the U.S. Fish Commission steamer 'Albatross' in 1888, and from other sources. Proceedings of the United States National Museum 14: 173-191.

Dautzenberg P, Fischer H (1906) Mollusques provenant des dragages effectués à l'ouest de l'Afrique pendant les campagnes scientifiques de S.A.S. le Prince de Monaco. Resultats des Campagnes scientifiques du Prince Albert I 32: 1-125, pls 1-5.

Deshayes GP (1857) Note sur différents Mollusques de la Guadeloupe, Envoyés par M. Schramm. Journal de Conchyliologie 6: 137-143.

Duarte JC, Rosas F, Pinheiro LM, Matias LM, Carvalho AM, Terrinha P, Ivanov M (2005) Interpretation of recent sedimentary and tectonic structures off SW Iberia from multibeam bathymetry, seismic reflection and experimental modelling. Geophysical Research Abstracts 7, 07867.

Duperron S, Halary S, Lorion J, Sibuet M, Gaill F (2008) Unexpected co-occurrence of six bacterial symbionts in the gills of the cold seep mussel Idas sp. (Bivalvia: Mytilidae). Environmental Microbiology 10(2): 433-445. doi:10.1111/j.1462-2920.2007.01465.x

Fisher CR (1990) Chemoautotrophic and methanotrophic symbioses in marine invertebrates. Review Aquatic Science 2: 399-436. 
Gardner JM (2001) Mud volcanoes revealed and sampled on the Western Moroccan continental margin. Geophysical Research Letters 28: 339-342.

Gebruk AV, Krylova EM, Lein AY, Vinogradov GM, Anderson E, Pimenov NV, Cherkashev GA, Crane K (2003) Methane seep community of the Haakon Mosby mud volcano (the Norwegian Sea): composition and trophic aspects. Sarsia 88: 394-403.

Génio L, Johnson SB, Vrijenhoek RC, Cunha MR, Tyler PA, Kiel SK, Little CTS (2008) New record of "Bathymodiolus" mauritanicus Cosel 2002 from the Gulf of Cadiz (NE Atlantic) mud volcanoes. Journal of Shellfish Research 27(1): 1-9.

Hensen C, Nuzzo M, Hornibrook E, Pinheiro LM, Bock B, Magalhães VH, Bruckmann W (2007) Sources of mud volcanoes fluids in the Gulf of Cadiz - indications for hydrothermal imprint. Geochimica et Cosmochimica Acta 71: 1232-1248.

Juniper SK, Tunnicliffe V, Southward EC (1992) Hydrothermal vents in turbidite sediments on a Northeast Pacific spreading centre: organisms and substratum at an ocean drilling site. Canadian Journal of Zoology 70: 1792-1809.

Kamenev GM (2009) North Pacific species of the genus Solemya Lamarck, 1818 (Bivalvia: Solemyidae), with notes on Acharax johnsoni (Dall, 1891). Malacologia 51(2): 233-261.

Kenyon NH, Ivanov MK, Akhmetzhanov AM, Akhmanov GG (Eds) (2000) Multidisciplinary study of geological processes on the North East Atlantic and Western Mediterranean Sea Margins. Preliminary results of geological and geophysical investigations during the TTR9 cruise of R/V Professor Logachev June-July, 1999. Intergovernmental Oceanographic Commission (IOC) Technical Series 56, UNESCO, Paris, 102 pp.

Kenyon NH, Ivanov MK, Akhmetzhanov AM, Akhmanov GG (Eds) (2001) Interdisciplinary approaches to geoscience on the North East Atlantic Margin and Mid-Atlantic Ridge. Preliminary results of investigations during the TTR-10 cruise of RV Professor Logachev. July-August, 2000. IOC Technical Series 60. UNESCO, Paris, 104 pp.

Kenyon NH, Ivanov MK, Akhmetzhanov AM, Akhmanov GG (Eds) (2002) Geologica processes in the Mediterranean and Black Seas and North East Atlantic. Preliminary results of investigations during the TTR-11 cruise of RV Professor Logachev July-September, 2001. IOC Technical Series, 62, UNESCO, Paris, 89 pp.

Kenyon NH, Ivanov MK, Akhmetzhanov AM, Akhmanov GG (Eds) (2003) Interdisciplinary geoscience research on the Northeast Atlantic Margin, Mediterranean Sea and Mid-Atlantic Ridge. Preliminary results of investigations during the TTR-12 cruise of RV Professor Logachev June-August, 2002. IOC Technical Series 67, UNESCO, Paris, 112 pp.

Kenyon NH, Ivanov MK, Akhmetzhanov AM, Akhmanov GG (Eds) (2006) Interdisciplinary geoscience studies of the Gulf of Cadiz and Western Mediterranean basins. Preliminary results o investigations during the TTR-14 cruise of RV Professor Logachev July-September, 2004. IOC Technical Series 70, UNESCO, Paris, 115 pp.

Krylova EM, Janssen R (2006) Vesicomyidae from Edison Seamount (South Western Pacific: Papua New Guinea: New Ireland fore-arc basin) (Bivalvia: Glossoidea). Archiv für Molluskenkunde 135: 233-263.

Krylova EM, Sahling H (2006) Recent bivalve molluscs of the genus Calyptogena (Vesicomyidae). Journal of Molluscan Studies 72: 359-395. doi:10.1093/mollus/eyl022 
Krylova EM, Sahling H (2010) Vesicomyidae (Bivalvia): Current taxonomy and distribution.

Plos One 5(4): e9957. doi:10.1371/journal.pone.0009957

Krylova EM, Sahling H, Janssen R (2010) Abyssogena: a new genus of the family Vesicomyidae

(Bivalvia) from deep-water vents and seeps. Journal of Molluscan Studies 76: 107-132.

Kuroda T (1948) Two new gigantic species of Solemya. Venus 15(1-4): 29-32. doi:10.1093/ mollus/eyp052

Levin L (2005) Ecology of cold seep sediments interactions of fauna with flow chemistry and microbes. Oceanography and Marine Biology: An Annual Review 43: 1-46. doi:10.1201/9781420037449.ch1

Magalhães VH (2007) Authigenic carbonates and fluid escape structures in the Gulf of Cadiz. PhD thesis, Universidade de Aveiro, 422 pp.

Mazurenko LL, Soloviev VA, Belenkaya I, Ivanov MK, Pinheiro LM (2002) Mud volcano gas hydrates in the Gulf of Cadiz. Terra Nova 14: 321-329. doi:10.1046/j.13653121.2002.00428.x

Métivier B, Cosel R von (1993) Acharax alinae n. sp. Solemyidae (Mollusca: Bivalvia) géante du bassin de Lau. Académie des Sciences (Paris), Comptes Rendu de Seances (3- Sciences de la Vie) 316: 229-237.

Mikkelsen PM, Bieler R (2008) Seashells of Southern Florida - Living Marine Mollusks of the Florida Keys and Adjacent Regions: Bivalves. Princeton University Press, Princeton, New Jersey, 503 pp.

Neulinger SC, Sahling H, Süling J, Imhoff JF (2006) Presence of two phylogenetically distinct groups in the deep-sea mussel Acharax (Mollusca: Bivalvia: Solemyidae). Marine Ecology Progress Series 312: 161-168. doi:10.3354/meps312161

Niemann H, Duarte J, Hensen C, Omoregie E, Magalhães VH, Elvert M, Pinheiro LM, Kopf A, Boetius A (2006) Microbial methane turnover at mud volcanoes of the Gulf of Cadiz. Geochimica et Cosmochimica Acta 70: 5336-5355. doi:10.1016/j.gca.2006.08.010

Okutani T, Métivier B (1986) Descriptions of three new species of vesicomyid Bivalves collected by the Submersible Nautile from the Abyssal depths off Honshu, Japan. Venus 45: $147-160$.

Okutani T, Hashimoto J, Miura T (2003) A new species of solemyid bivalve from near submarine fumaroles in Kagoshima Bay, Japan. Venus 62(3-4): 91-96.

Oliver PG, Holmes AM (2006a) A new species of Lucinoma (Bivalvia: Lucinoidea) from the oxygen minimum zone of the Oman Margin, Arabian Sea. Journal of Conchology 39 (1): 63-77.

Oliver PG, Holmes AM (2006b) New species of Thyasiridae (Bivalvia) from chemosynthetic communities in the Atlantic Ocean. Journal of Conchology 39 (2): 175-183.

Oliver PG, Taylor JD (submitted) Bacterial chemosymbiosis in the Nucinellidae (Mollusca: Bivalvia) with descriptions of two new species.

Olu K, Lance S, Sibuet M, Henry P, Fiala-Médioni A, Dinet A (1997) Cold seeps communities as indicators of fluid expulsion patterns through mud volcanoes seaward of the Barbados accretionary prism. Deep-Sea Research I 44(5): 811-841. doi:10.1016/S09670637(96)00123-9

Olu-Le Roy K, Sibuet M, Fiala-Médioni A, Gofas S, Salas C, Mariotti A, Foucher JP, Woodside J (2004) Cold seep communities in the deep eastern Mediterranean Sea: composition, 
symbiosis and spatial distribution on mud volcanoes. Deep-Sea Research I 51: 1915-1936. doi:10.1016/j.dsr.2004.07.004

Olu-Le Roy K, Caprais JC, Fifis A, Fabri MC, Galeron J, Budzinsky H, Le Menach K, Khripounoff A, Ondreas H, Sibuet M (2007) Cold-seep assemblages on a giant pockmark off West Africa: spatial patterns and environmental control. Marine Ecology 28(1): 115-130. doi:10.1111/j.1439-0485.2006.00145.x

Pinheiro LM, Ivanov MK, Sautkin A, Akhamanov G, Magalhães VH, Volkonskaya A, Monteiro JH, Somoza L, Gardner J, Hamouni N, Cunha MR (2003) Mud volcanoes in the Gulf of Cadiz: results from the TTR-10 cruise. Marine Geology 195: 131-151. doi:10.1016/ S0025-3227(02)00685-0

Ravara A, Cunha MR, Rodrigues CF (2007) The occurrence of Natsushima bifurcata (Polychaeta: Nautiliniellidae) in Acharax hosts from mud volcanoes in the Gulf of Cadiz (south Iberian and north Moroccan Margins). Scientia Marina 71(1).

Rodrigues CF (2009) Comunidades macrobentónicas dos vulcôes de lama do Golfo de Cádis// Macrofaunal assemblages from mud volcanoes of the Gulf of Cadiz. Departamento de Biologia, Universidade de Aveiro, Aveiro, 348 pp.

Rodrigues CF, Duperron S (2011) Distinct symbiont lineages in three thyasirid species (Bivalvia: Thyasiridae) from the eastern Atlantic and Mediterranean sea. Naturwissenchaften, 98(4): 281-287. doi:10.1007/s00114-011-0766-3

Rodrigues CF, Duperron S, Gaudron SM (2011) First documented record of a living solemyid bivalve in a pockmark of the Nile Deep-sea Fan (eastern Mediterranean Sea). Marine Biodiversity Records 4: e10. doi:10.1017/S175526721100008X

Rodrigues CF, Oliver PG, Cunha MR (2008) Thyasiroidea (Mollusca: Bivalvia) from the mud volcanoes of the Gulf of Cadiz (NE Atlantic). Zootaxa 1752: 41-56.

Rodrigues CF, Webster G, Cunha MR, Duperron S, Weightman AJ (2010) Chemosynthetic bacteria found in Bivalvia species from mud volcanoes of the Gulf of Cadiz. FEMS Microbial Ecology 73(3): 486-499.

Sahling H, Galkin SV, Salyuk A, Greinert J, Foerstel H, Piepenburg D, Suess E (2003) Depthrelated structure and ecological significance of cold-seep communities - a case study from the Sea of Okhotsk. Deep Sea Research I 50: 1391-1409. doi:10.1016/j.dsr.2003.08.004

Salas C, Woodside J (2002) Lucinoma kazani n. sp. (Mollusca: Bivalvia): evidence of a living benthic community associated with a cold seep in the eastern Mediterranean Sea. Deep-Sea Research Part 1 49: 991-1005. doi:10.1016/S0967-0637(02)00010-9

Say T (1822) An account of some of the marine shells of the United States. Journal of the Academy of Natural Sciences of Philadelphia 2: 221-248, 257-276, 302-325.

Sibuet M, Olu K (1998) Biogeography, biodiversity and fluid dependence of deep-sea coldseep communities at active and passive margins. Deep-Sea Research II 45: 517-567. doi:10.1016/S0967-0645(97)00074-X

Sibuet M, Olu-Le Roy K (2002) Cold Seep Communities on Continental Margins: Structure and Quantitative Distribution Relative to Geological and Fluid Venting Patterns. In: Weffer G, Billett D, Hebbeln D, Jorgersen BB, Van Weering TJ (Eds) Ocean Margin System, Springer Verlag, 235-251. 
Stadnitskaia A, Ivanov MK, Blinova V, Kreulen R, van Weering TCE (2006) Molecular and carbon isotopic variability of hydrocarbon gases from mud volcanoes in the Gulf of Cadiz, NE Atlantic. Marine and Petroleum Geology 23: 281-296.

Stimpson, W (1851) A revision of the synonymy of the testaceous mollusks of New England. Phillips, Sampson \& Company, Boston, 56 pp, 2 pls.

Sturany R (1896) Mollusken I (Prosobranchier und Opisthobranchier, Scaphopoden; Lamellibranchier) gesammelt von S. M. Schiff "Pola" 1890-94. Denkschriften der mathematischnaturwissenschaftlichen Klasse der Kaiserlichen Akademie der Wissenschaften, Wien 63: 1-36, pls 1-2.

Taylor JD, Glover EA (2006) Lucinidae (Bivalvia) - the most diverse group of chemosymbiotic molluscs. Zoological Journal of the Linnean Society 148(3): 421-438. doi:10.1111/ j.1096-3642.2006.00261.x

Taylor JD, Glover EA (2009) New lucinid bivalves from hydrocarbon seeps of the Western Atlantic (Mollusca: Bivalvia: Lucinidae). Steenstrupia 30(2): 127-140.

Taylor JD, Glover EA, Williams ST (2008) Ancient chemosynthetic bivalves: systematics of Solemyidae from eastern and southern Australia (Mollusca: Bivalvia). In: Davie PJF, Philips JA (Eds) Proceedings of the Thirteenth International Marine Biological Workshop, The Marine Fauna and Flora of Moreton Bay, Queensland. Memoirs of the Queensland Museum - Nature 54(1): 75-104.

Thiele J, Jaeckel S (1931) Muscheln der deutschen Tiefsee-Expedition. Wissenschaften Ergbnisse der Deutschen Tiefsee-Expedition auf der Dampfer "Valdivia" 1898-1899, 21: $161-268$.

Totten JG (1834) Description of some new shells, belonging to the coast of New England American. Journal of Science and Arts 26: 366-369.

Tunnicliffe V (1991) The biology of hydrothermal vents: ecology and evolution. Oceanography Marine Biology 29: 219-407.

Turner RD (1985) Notes on mollusks of deep-sea vents and reducing sediments. American Malacological Bulletin (Special Edition ) 1: 23-34.

Van Rensbergen P, Depreiter D, Pannemans B, Moerkerke G, Van Rooij D, Marsset B, Akhmanov G, Blinova V, Ivanov M, Rachidi M, Magalhães V, Pinheiro L, Cunha M, Henriet JP (2005) The El Arraiche mud volcano field at the Moroccan Atlantic slope, Gulf of Cadiz. Marine Geology 219 (1): 1-17. doi:10.1016/j.margeo.2005.04.007

Verrill AE, Bush KJ (1898) Revision of the deep-water Mollusca of the Atlantic coast of North America, with descriptions of new genera and species. Proceedings of the United States National Museum 20: 775-901.

Vokes HE (1970) Two new species of deep water bivalves from the Caribbean Sea. Veliger 12(3): 357-361.

Warén A, Bouchet P (2009) New gastropods from deep-sea hydrocarbon seeps off West Africa. Deep-Sea Research II 56: 2326-2349. doi:10.1016/j.dsr2.2009.04.013

Zitellini N, Gràcia E, Matias L, Terrinha P, Abreu MA, DeAlteriis G, Henriet JP, Dañobeitia JJ, Masson DG, Mulder T, Ramella R, Somoza L, Diez S (2009) The quest for the AfricaEurasia plate boundary west of the Strait of Gibraltar. Earth and Planetary Science Letters 208(1-4): 13-50. doi:10.1016/j.dsr2.2009.04.013 